\title{
Danger to the Old Lady of Threadneedle Street? The Bank Restriction Act and the regime shift to paper money, 1797-1821
}

DOI:

10.1093/ereh/hez008

\section{Document Version}

Accepted author manuscript

Link to publication record in Manchester Research Explorer

Citation for published version (APA):

O'Brien, P. K., \& Palma, N. (2020). Danger to the Old Lady of Threadneedle Street? The Bank Restriction Act and the regime shift to paper money, 1797-1821. European Review of Economic History.

https://doi.org/10.1093/ereh/hez008

\section{Published in:}

European Review of Economic History

\section{Citing this paper}

Please note that where the full-text provided on Manchester Research Explorer is the Author Accepted Manuscript or Proof version this may differ from the final Published version. If citing, it is advised that you check and use the publisher's definitive version.

\section{General rights}

Copyright and moral rights for the publications made accessible in the Research Explorer are retained by the authors and/or other copyright owners and it is a condition of accessing publications that users recognise and abide by the legal requirements associated with these rights.

\section{Takedown policy}

If you believe that this document breaches copyright please refer to the University of Manchester's Takedown Procedures [http://man.ac.uk/04Y6Bo] or contact uml.scholarlycommunications@manchester.ac.uk providing relevant details, so we can investigate your claim.

\section{OPEN ACCESS}




\title{
Centre for Global
} Economic History

\section{CGEH Working Paper Series}

\section{Danger To The Old Lady Of Threadneedle Street? The Bank Restriction Act And The Regime Shift To Paper Money, 1797-18211}

\author{
Patrick K. O’Brien, London School of Economics \\ Nuno Palma, University of Manchester; Instituto de Ciências \\ Sociais, Universidade de Lisboa; CEPR
}

July 2019

Working paper no. 82

www.cgeh.n1/working-paper-series/ 


\title{
Danger To The Old Lady Of Threadneedle Street? The Bank Restriction Act And The Regime Shift To Paper Money, 1797-18211
}

\author{
Patrick K. O’Brien, London School of Economics \\ Nuno Palma, University of Manchester; Instituto de Ciências Sociais, Universidade de \\ Lisboa; CEPR
}

\begin{abstract}
The Bank Restriction Act of 1797 was the unconventional monetary policy of its time. It suspended the convertibility of the Bank of England's notes into gold, a policy which lasted until 1821. The current historical consensus is that it was a result of the state's need to finance the war, France's remonetization, a loss of confidence in the English country banks, and a run on the Bank of England's reserves following a landing of French troops in Wales. We argue that while these factors help us understand the timing of the suspension, they cannot explain its success. We deploy new long-term data which leads us to a complementary explanation: the policy succeeded thanks to the reputation of the Bank of England, achieved through a century of prudential collaboration between the Bank and the Treasury.
\end{abstract}

Keywords: Bank of England, financial revolution, fiat money, money supply, monetary policy com- mitment, reputation, time-consistency, regime shift

JEL Codes: N13, N23, N43.

Corresponding author: Nuno Palma,nuno.palma@manchester.ac.uk.

Acknowledgements: We are grateful to Pamfili Antipa, Adam Brzezinski, Mark Dincecco, Rui Esteves, Alex Green, Marjolein 't Hart, Phillip Hoffman, Alejandra Irigoin, Richard Kleer, Kevin O'Rourke, Jaime Reis, Albrecht Ritschl, Lisbeth Rodrigues, Joan R. Rosés, Rebecca Simson, Stephen Timmons, François Velde, Jan Luiten van Zanden, and especially Joost Jonker and Christopher M. Meissner for comments and discussions. The usual disclaimer applies. Some of the work in this paper previously circulated as LSE Department of Economic History Working Paper No. 156/11, which was in turn partly based on O'Brien's unpublished Oxford DPhil. Financial support to Nuno Palma from Fundação para a Ciência e a Tecnologia (CEECIND/04197/2017) is gratefully acknowledged. 


\section{Introduction}

Britain's first war against Revolutionary France (1793-1802) was associated with a series of financial panics and runs on banks in Britain. ${ }^{2}$ As a result, the Bank of England's reserves suffered a significant drain from 1795 onwards. Partially in response to that, the Bank of England suspended the convertibility of its notes into gold on Monday $27^{\text {th }}$ February 1797. This decision had Pitt's agreement and was later also confirmed by the Bank Restriction Act, passed by Parliament on May $3^{\text {rd }}, 1797 .{ }^{3}$ While initially announced to last one year, it was later decided that the suspension of convertibility was to be extended until a definite peace had been signed. ${ }^{4}$ This decision was a success. It saved the Bank from insolvency, inflation stayed at moderate levels, and there was no effect on the long-term (consol) interest rates on secondary markets. Despite Bank of England notes becoming more common as a means of payment, their discount remained moderate as well, and no major financial crisis resulted. ${ }^{5}$ In the words of Schumpeter (1987/1954, pp. 690-1): "In spite of the suspension ... war finance did not produce any great effects upon prices and foreign exchange-rates until about 1800. To the modern student who is inured to stronger stuff, the most striking feature of the subsequent inflation is its mildness ... at no time was the government driven to do anything more unorthodox than abnormally heavy borrowing from the Bank, and even this borrowing never surpassed the limits beyond which the term 'borrowing' becomes an euphemism for printing government fiat."

Why was the Restriction possible, and why did it succeed? The current historical consensus is that it occurred as a response to short-term pressures: the state's need to finance the war, France's remonetisation following the end of the assignats monetary regime, a loss of confidence in the country banks, and the run on the Bank of England's reserves (Feavearyear 1931, p. 173; Roberds and Velde 2016, p. 471, Chadha and Newby 2013, p. 5). We argue that these factors help us understand the timing of the Restriction period, but not its success. On their own, these short-term pressures do not

\footnotetext{
${ }^{2}$ We take our title from a contemporary cartoon by James Gillray, which depicts the Bank of England as an old lady covered in $£ 1$ and $£^{2}$ banknotes, complaining that the Prime Minister Pitt was endangering her reputation in order to pay his debts (see Figure A1 in our appendix).

3 The possibility of suspension was being discussed by Pitt, the Bank, and other bankers and merchants since January 1797 (Clapham 2008a, p. 271). Once the news of a French landing in Wales reached London on the $25^{\text {th }}$ of February, the Privy Council, which met the following day, decided to suspend convertibility, a decision communicated to the Bank of England late that night. For a recent account of these events, see Chadha and Newby (2013, pp. 5-7).

${ }^{4}$ As it were, the policy lasted until 1821. Peel's resumption bill was passed in 1819; actual resumption of specie payments by the Bank of England took place in 1821.

${ }_{5}$ The South American bubble, which burst in 1810 leading to a commercial crisis (and to the hostile Bullion Report of 1810 which was hostile to the Bank), had not been stimulated by the Bank (Clapham 2008b, p. 20).

${ }_{6}$ The pound only depreciated $30 \%$ between 1797 and 1815 , which is remarkable in comparison to the French and American counterpart experiments (Kynaston 2017, p. 89). As we discuss below, it is doubtful that even this comparatively small discount can be attributed to the Bank of England's actions.
} 
explain why people trusted the Bank's inconvertible notes. ${ }^{7}$

In this paper we deploy novel long-term data which leads us to a complementary explanation: the Restriction Period succeeded thanks to the reputation of the Bank of England, achieved through a century of prudent behavior. Faced with an unusually serious possibility of military invasion, the country's elites were willing to tolerate the risk associated with suspension, and merchants as well as regular citizens accepted the notes at historically low levels of discount. The Restriction also led to a long-term unintended consequence in the form of a shift to a bullion standard where banknotes played an important role. It was from this episode onwards that the age of paper money truly began, despite the full restoration of convertibility at the inauguration of a (mixed) gold coin standard in $1821 .^{8}$

To make our case, we document quantitatively, for the first time, the timing of the expansion of paper money relative to coin supply in England during the eighteenth century and beyond, with a particular focus on the run-up to the Restriction Period, which we identify as encompassing a regime shift. We analyze the process through which the Bank of England accumulated a credible reputation over time and the checks and balances that allowed for its increasing role as manager of the public debt work. We also investigate how bankers in London and in the provinces reacted to specific events and policy measures.

A study of the history of the Bank is complementary to our understanding of the building-up of the government's reputation, a matter which has received a great deal of attention in the economic history literature. While Bordo and White (1991) focus on the credibility of the public finances of the British State, our focus here is on the credibility of the outstanding liabilities of one particular institution, the Bank of England. We hence argue that the credible commitment underpinning the success of British public finance consisted of two parts: the government's commitment to sound public finance, and the Bank's commitment to providing both public and private credit.

In this paper we focus on the latter, and in particular on the matter of how by the late eight-

\footnotetext{
${ }^{7}$ A similar attempt to create an analogous bank for the Netherlands - the Bank of Amsterdam did not issue notes, lend to the government, or operate a discount window - failed, as the public did not consider the banknotes credible ( $t$ 'Hart et al 1997, p. 96).

${ }^{8}$ By paper money we do not here mean fiat (despite the Restriction Period being sometimes known as the period of the "Paper Pound"). Instead we mean that, as a result of this episode, banknotes became a widespread form of payment. The key difference between paper money and fiat money is that the former is backed (e.g. by gold reserves) while the latter is inconvertible. It is evidently the case, however, that even when paper money is in supposedly backed, there is an element of credibility determining whether it circulates at a discount.
} 
eenth century the Bank managed to implement a set of monetary policies that were highly unconventional by the standards of the time, with a good measure of success. According to some authors, the Suspension was an inflationary policy geared towards increasing the government's seigniorage revenues (Bordo and Kydland 1995; Bordo and Redish 1993). However, while it is true that the government did take advantage of the liquidity provided by the Bank, most of the profits from issuing paper money went to the Bank's shareholders, not to the government (O'Brien 1967; Roberds and Velde 2016, p. 471). Others argue that increasing private profits was the point of the suspension (Ricardo 1951/1811). By contrast, Chadha and Newby (2013) argue that through the Restriction the Bank of England was able to reach a closer alignment of the duration of its liabilities and assets, as well as providing some war finance to the government "by allowing some leverage in its loans relative to its market value" (p. 3). Our interpretation is closer to this viewpoint, but while Chadha and Newby (2013) focus exclusively on the period after 1793, we argue that understanding the success of the Restriction Period requires thinking about the public's trust, which implies taking a longer-term view.

While the reputation of the state and the Bank of England were separate, they cannot be said to have been fully independent. On the one hand, the Bank of England lent considerable amounts to the government, and assisted in the formation of an effective fiscal-naval state in Britain, while at the same time promoting the development of a system of financial intermediation for the economy as a whole (O'Brien and Palma 2019). But on the other hand the state's fiscal innovations, high fiscal capacity, and reliance on the sinking fund, constrained by Parliamentary oversight, meant it could borrow and had sufficient revenue to pay the loans to the Bank, while committing not to monetize the debt beyond certain limits. ${ }^{9}$ But despite this interdependence, the Bank never simply followed orders from the government, as has been frequently argued in the literature. For instance, Antipa (2016, p. 1052) writes that "The Bank could hardly refuse requests for credit from the Treasury in times of war". But as we discuss below, this was not the case; there were numerous instances of the Bank denying credit to the government, including at times of war. We argue that it was the Bank's century-long commitment to prudence with regards to monetary expansion that pathed the way for the Restriction's success. This finding complements more recent literature on the importance of central bank independence for its credibility (Bordo and Siklos, 2015).

\footnotetext{
${ }^{9}$ During the suspension, the Bank's notes were to a large extent (though not exclusively) the counterpart to public securities held by the Bank as reserves. So the Treasury's reputation as a good debtor mattered for the credibility of the Bank's notes (an important component of the Bank's liabilities), which depended on the securities that backed them.
} 


\section{Why was the Suspension possible?}

\subsection{Historical background}

Between 1694 and 1821, the national supply of money and credit consisted of gold, silver and copper coins, privately issued tokens, bills of exchange, and the liabilities of banks, including notes of the Bank of England, notes of private country banks of issue and bankers' deposits. Bills of exchange in the hands of businessmen may have been an important component of the nation's money supply in certain parts of the country (Ashton 1953). Bank deposits were not generally employed as a means of payment in the provinces, and even if within the capital cheques and drafts upon bankers could at times have exceeded the value of Bank of England notes in circulation, this was certainly not the case elsewhere. Until surprisingly late it was coin that dominated the money supply (Table 1).

\begin{tabular}{cccccccc}
\hline & $\begin{array}{c}1600 \\
(\text { Mayhew })\end{array}$ & $\begin{array}{c}1688 \\
(\text { Cameron })\end{array}$ & $\begin{array}{c}1700 \\
(\text { Capie })\end{array}$ & $\begin{array}{c}1750 \\
(\text { Cameron })\end{array}$ & $\begin{array}{c}1750 \\
(\text { Capie })\end{array}$ & $\begin{array}{c}1790 \\
(\text { Capie })\end{array}$ & $\begin{array}{c}1870 \\
(\text { Capie })\end{array}$ \\
\hline $\begin{array}{c}\text { Coin } \\
\begin{array}{c}\text { Bank of England } \\
\text { notes }\end{array}\end{array}$ & 3.5 & 10 & 7 & 15 & 18 & 44 & 95 \\
\hline $\begin{array}{c}\text { Other notes (country } \\
\text { banknotes) }\end{array}$ & - & - & 1.5 & 4.3 & 4 & 8 & 35 \\
\hline $\begin{array}{c}\text { Bank balances at the } \\
\text { bank of England }\end{array}$ & - & - & - & 0.7 & 1 & 4 & 4.9 \\
\hline $\begin{array}{c}\text { Other means of } \\
\text { payment }\end{array}$ & 1 & 10 & $\mathrm{n} / \mathrm{a}$ & 18.1 & $\mathrm{n} / \mathrm{a}$ & $\mathrm{n} / \mathrm{a}$ & $\mathrm{n} / \mathrm{a}$ \\
\hline Total $(\mathrm{M} 2)$ & 4.5 & 20 & $>8.5$ & 40 & $>23$ & $>56$ & $>141.4$ \\
\hline
\end{tabular}

Table 1. Estimates for various components of English nominal money supply. Unit: $£$ m. Sources: Mayhew (2013), Capie (2004) and Cameron (1967). The category "other means of payment" includes Cameron’s £6m in government tallies and $£ 2 \mathrm{~m}$ in inland bills in 1688 and $£ 3.1 \mathrm{~m}$ in deposits in private banks in 1750 .

Much of the development of the English financial system during the eighteenth century can be represented as catching up with best practices on the continent (Coffman et al 2013). Nonetheless, after almost a century of growth of financial intermediation under the auspices of the Bank of England, by the outbreak of the French Revolution a number of goldsmiths had turned into proper banks (Temin and Voth 2006). By then, the scale, density and spread of provincial banks had reached a level where the British economy conducted a non-negligible share of its wholesale transactions with bank notes, deposits and other forms of paper credit (negotiable bills of exchange). ${ }^{10}$

10 At least prior to the Restriction, circulation of country banknotes was "far below that of the Bank" (Clapham 1944, p. 265), and the practice of deposit banking was more advanced in eighteenth century Britain than in contemporary Amsterdam (Jonker 1996, pp. 233-6, Quinn and Roberds 2016, p.78). In the Netherlands, money of account was additionally used to record credit granted to counterparts (Gelderblom and Jonker 2015), but it remains to be de- 
Bills of exchange were convertible with greater ease than anywhere outside the Netherlands into the liabilities of specialized institutions for the funding of trade, agriculture and industry, as well as the state (Ashton 1953). But their circulation at the retail and wage-paying levels nevertheless remained limited, and it was only with the Bank restriction act of 1797 that non-coined money really took off (Figure 1). Indicators such as popular acceptance and legal status suggest that (despite officially non-legal tender until later) only Bank of England notes were in practice commonly accepted as money. ${ }^{11}$ During the $1793-1815$ war years, when specie became increasingly scarce in circulation, Bank notes increased their importance as a form of reserve money, and became much more common as a means of payment. ${ }^{12}$ The increase in Bank of England note circulation was an important part of the dramatic increase of importance of $\mathrm{M} 2$ relative to coin supply which took place from the 1790 s onwards (Figure 2). ${ }^{13}$

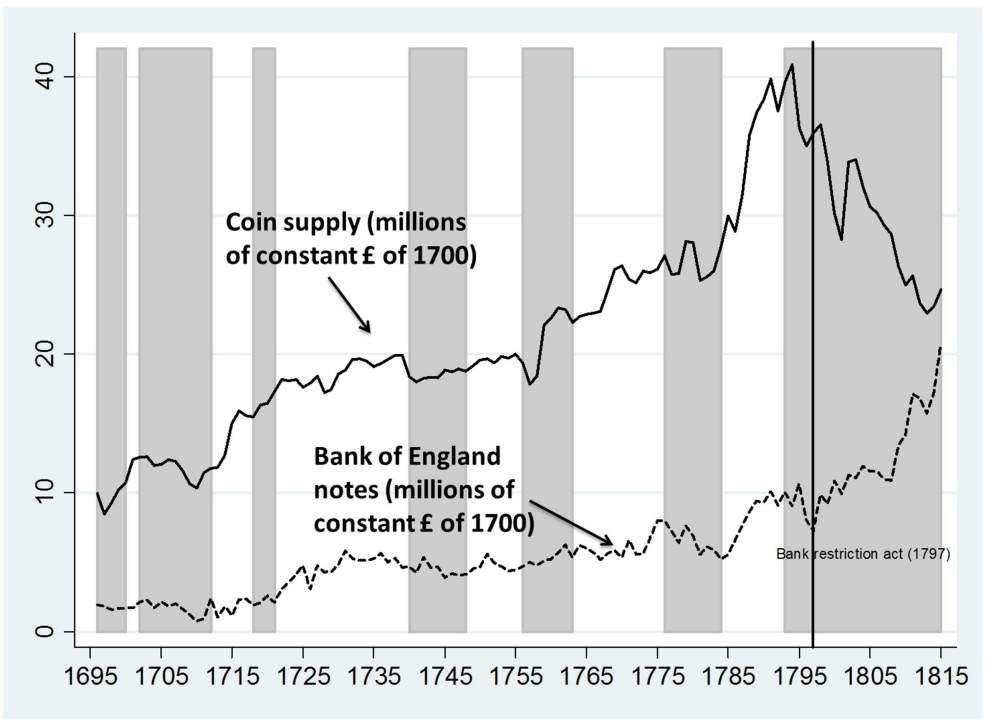

Figure 1. Coin supply and Bank of England notes, at constant prices of 1700. Grey shaded areas represent years of war. The black vertical line marks the year of the Bank Restriction Act. Sources: Bank of England (1967), Palma (2018a); for the deflator, Broadberry et al (2015).

termined if these practices were used in Britain. Nevertheless, "From the 1770s, private banks started to formalize ways of clearing inter-bank payments, resulting from customer transactions, and used Bank notes to settle amounts outstanding between themselves" (Hotson 2012, p. 12).

${ }_{11}$ This stands in contrast with the case of country banknotes, Land Bank notes, goldsmith-banker notes, bills of exchange, tallies, mortgages, and annuity securities (Horsefield 1977).

${ }^{12}$ Feavearyear (1931, p. 192) writes that "Not only was the country losing its gold, but it looked as though it would lose all its other metallic money as well". Below we review in detail the evidence showing that Bank of England notes became more prevalent for everyday payments.

${ }^{13}$ By M2 we refer here to Palma's (2018a) broad money aggregate for the pre-1870 period. It is to be distinguished from the Bank of England's modern day measure of M2. 


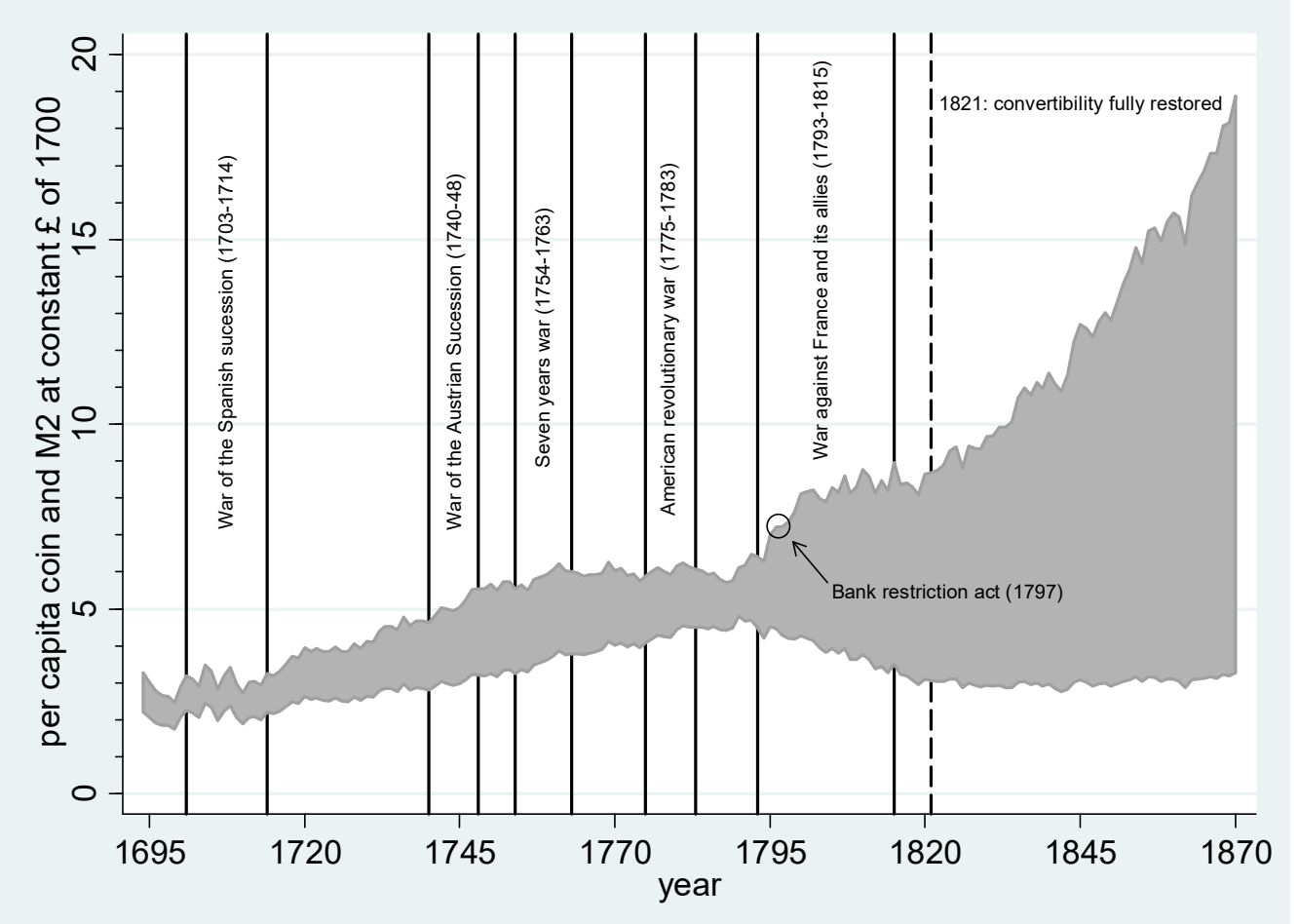

Figure 2. British per capita coin supply (lower line) and M2 (higher line), at constant prices of 1700 . The area in grey can be interpreted as the approximate size of non-coin money in circulation or held as store of value. Dashed vertical line corresponds to 1821 , when convertibility was restored. The figure is derived using the indirect method described in Palma (2018a).

\subsection{Origins of the restriction period: the traditional narratives}

There is reasonably broad agreement in the literature about some basic facts which characterize the Restriction Period. For long stretches of the eighteenth century the supplies of coins only barely satisfied the economy's growing demands for fractional payments. The seriousness of this problem intensified in the run up to, and during, the wars with France (1793-1815) when the event which was known to contemporaries as the "bullion crisis" occurred: an expectations-driven "flightto-quality" increased levels of hoarding and increased the market price for bullion (Figure 3) to a point that for a short period of time coins greatly decreased from circulation (as seen in Figure 1). ${ }^{14}$

The divergence between the official and market price in gold shown in Figure 3 cannot be attributed to the policies of the Bank of England, unlike what the bullionists argued. Instead, it was the result of

\footnotetext{
${ }^{14}$ Nonetheless notice that "There was no permanent and important divergence between the market price of gold and the mint prince before 1808: margins were known to bullion dealers, not ordinary people” (Clapham 2008b, p. 8). See also Feavearyear (1931, pp. 169, 183 and 187), Pressnell (1956, p. 159), Committee of the House of Commons on Suspension 1797, in Parliamentary Papers (1826); Thornton (1802, p. 97); and Mathias (2004, pp. 68-83).
} 
Napoleon's overthrow of the Directory in 1799, and of his subsequent victories. As the graph shows, conditions were back to normal shortly after Waterloo, much before a date for resumption had been decided. The rising agio (difference between the market price and the mint price) cannot hence be straightforwardly interpreted as representing rising public expectations of future inflation (as done by Antipa 2016). Inflation had been rising since the late 1780 s and it is more likely that the public attributed the agio's behavior to the perceived bad state of the coinage (Feavearyear 1931). ${ }^{15}$ We agree with Antipa (2016, p. 1049) that Britain's military fortunes could in part determine changes in the agio; but the data do not bear out her conclusion that the agio declined "after the resumption of the gold standard in 1821" (p. 1050). ${ }^{16}$ As the banking school (the intellectual successor to the real bills and Birmingham schools, which opposed the bullionists) would argue in the 1840s, deposits and bills of exchange are also money which means that the way to avoid inflation is to focus on the growth of bank credit, not note-issuing per se.

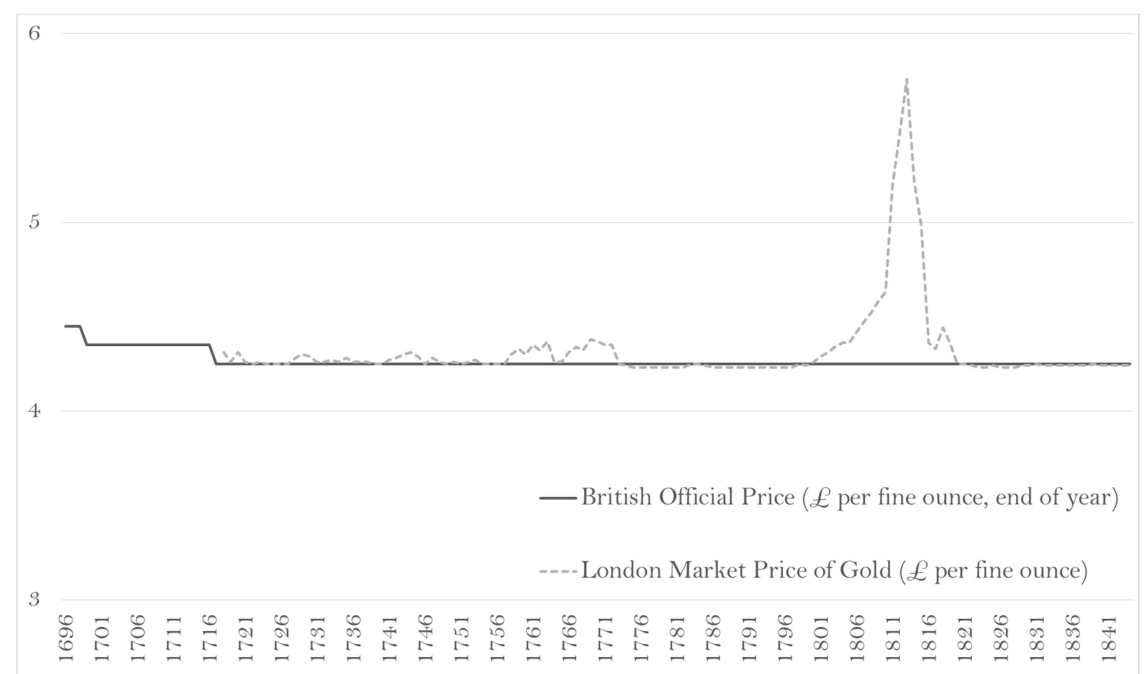

Figure 3. Official and market price of gold, in $£$ per fine ounce. Source: Officer and Williamson (2016a).

When market prices increased, people got more money for their precious metals on the market than at the mint. Minting decreased (at times ceasing altogether) because there was a better deal to be made on the market. $£ 1, £ 2$, and $£ 5$ bills were issued by the Bank, and by provincial banks, to replace the hoarded (or exported) specie as a means of payment. It is tempting to interpret this shift in terms of Gresham's law, but we do not favor that interpretation because "without some private information we would not observe either the phenomenon of circulation by tale or Gresham's Law, since these both revolve around what happens when one meets a uninformed seller." (Velde et al. 1999; see also Redish 2000, p. 30). Gresham’s law hence cannot apply here, as no one would have had

\footnotetext{
15 We discuss inflation (and its relation to the actions of the Bank of England) in detail in section 3.2., below.

${ }^{16}$ Antipa's own Figure 3 in p. 1050 clearly shows that the agio was declining well before resumption.
} 
any difficulty distinguishing Bank of England notes from coin. ${ }^{17}$

Notes issued by the Bank increased dramatically after 1797 to circumvent the problem left by the negligence (or incapacity) of the government to mint adequate supplies of coins, within the metropolitan area and increasingly in the provinces as well (Shin 2016). Precious metals were increasingly scarce as they were flowing to France which was remonetizing following the collapse of its paper currency system (Roberds and Velde 2016). The increase in the circulation of the Bank's notes in provinces contrasted with the situation prevailing until late in the eighteenth century, when Bank of England notes had seldom circulated beyond a thirty mile radius of central London. Furthermore, the dramatic expansion of the balance sheet of the Bank of England after 1797 was accompanied by a similar expansion of the balance sheets of provincial banks (Pressnell 1956). By the beginning of the Revolutionary War the amount of their notes outstanding throughout Great Britain probably equaled the issues by the Bank, and by the battle of Waterloo may have exceeded them. ${ }^{18}$ Nonetheless, this expansion would not have been possible without that of the Bank of England.

There are two reasons usually given in the literature for the Restriction Period. First, it was the result of demand for liquidity in the context of a military emergency. Second, it was the result of France's increased demand for precious metals following its return to a commodity-money system. As France's remonetization began to drain gold out of the country (a couple of years before Suspension) the Bank started rationing its discounts (Clapham 2008a). This was not enough to prevent the dwindling of the Bank's reserves, which fell from 8 million pounds sterling in 1791 to as just over 1 million during 1797. ${ }^{19}$ Evidently, these two motives interacted; and indeed, it would be too simplistic to say that the Suspension was simply due to the Bank's low reserves. During 1783-4, for instance, the Bank carried business for over a year with less bullion than at time of Suspension fourteen years later. This had been possible because "1783 was a year of peace with commercial prospects ... while 1797 was a year of dangerous war" (Clapham 2008a). From the 1790 s onwards, military subsidies to Britain's allies also drained gold out of the country.

\footnotetext{
${ }^{17}$ Instead, the agio evolved as shown in Figure 3; after some time coin gained a premium; equivalently, Bank of England notes gained a discount. Under Gresham's law this too is impossible, because this "law" assumes different currencies are accepted at the same nominal value (due to the difficulty the payee has in distinguishing coin quality without assaying it), which is what drives the payer selection of "bad" money when making payments.

${ }^{18}$ Coppieters (1955, p.1), Pressnell (1956, pp. 15, 16, 136, 142 and 159).

${ }^{19}$ Feavearyear (1931, p. 177). Roberds and Velde (2014) argue that following France's remonetisation, which started in the Spring of 1795, “[T] he subsequent drain on the Bank of England's reserves forced a suspension of convertibility of the Bank's notes in February 1797”. See also Feavearyear (1931, p. 167) or Clapham (1944, pp. 169-70). For the continental capital inflight to Britain after 1793, see Neal (1990, pp. 180, 216-7) and Neal (1991) or Clapham (1944, p. 257).
} 
These reasons are focused on the role of short-run pressures on the Bank's reserves. ${ }^{20} \mathrm{We}$ argue, however, that while such liquidity-type reasons are important (as necessary conditions), they cannot explain the Suspension's success. What mattered was that the British public and merchants accepted the new state of affairs. Doing so was mostly spontaneous on the part of the public but it was coordinated on the part of merchants. On Monday $27^{\text {th }}$ of February 1797, hundreds of leading merchants publicly agreed not to refuse Bank of England notes in payment, and to make provision to make all payments in such matters (Feavearyear 1931, p. 170; Shin 2015). Soon after, in March $2^{\text {nd }}$, an Act was passed which allowed the Bank to issue notes of less than $£ 5$, and Bank of England notes became more common all over the country (Feavearyear 1931, p. 171). The Bank of England's reserves grew back to 8 million by late 1799, and the public's confidence in most provincial banks was restored as well (Feavearyear 1931, p. 177).

The factors traditionally mentioned in the literature can help explain the timing of the Restriction Period, but they cannot explain why it worked, especially in light of similar but failed experiences in the continent - including in the Netherlands (t'Hart et al 1997, p. 96). To understand this success, we need to take a longer view; we argue that it was the Bank's long-run reputation which mattered. ${ }^{21}$ Indeed, the Bank's century-long prudence in monetary expansion signaled independence that further underpinned its credibility.

\subsection{A new, long-term and quantitative view}

All economies require liquidity, but they face restrictions in the form of access to precious metals or commitment problems which do not allow for paper money to be held and to circulate. Hence, demand for liquidity alone cannot explain the timing, or the sudden scale, of the adoption of paper money. In turn, short-term military pressure can help us understand the timing of the adoption, but cannot explain why earlier pressures of the same nature had not led to the same outcome. Nor can it explain why the policy ultimately succeeded, rather than turning into conventional debt monetization for fiscal purposes, which would have led to inflation and to the ultimate abandonment of the system, as happened in France. Equally, demand for precious metals

\footnotetext{
20 To these short-term pressures we must add two others which are not usually mentioned in the literature. First, this was also a period of limited access to precious metals for Europe as a whole. Precious metals, which Britain obtained through trade, were the critical input to the production of coin, and this motive combined with increasing hoarding levels to cause minting output to diminish to historically low levels (including several years of zero minting) from the $1790 \mathrm{~s}$ to the $1810 \mathrm{~s}$ (Challis 1992). Second, this was a period of robust economic growth in Britain, both at the intensive (per capita) and extensive (population) levels, as well as a period of structural change and increased urbanization. All of these factors increased the demand for banknotes as means of payment.

${ }^{21}$ Chadha and Newby (2013, p. 10) also place emphasis on the Bank's reputation as an important matter for the Restriction's success: "practical men of the City of London [which publicly committed not to refuse the Bank's notes] would not have supported policy in which they did not have faith, and therefore merchant's willingness to support the Bank notes can be seen as a testimony to the Bank's credibility".
} 
in France following the failure of its own paper money policy can explain why pressure was exerted on the equilibrium price of precious metals in Britain, but not why the adoption of the Restriction Period policies was possible as a way out.

In order to understand why the Restriction Period was possible and ultimately successful, we need to consider the history of the Bank prior to that event. So far, scholars have analyzed this mostly at a qualitative level. While the balance sheets of the Bank of England are well-known, economic historians have lacked comparable measures for both coin supply and broader forms of money, leading to the possibility of only analyzing the outcomes in a rather unsystematic manner, for years when information happens to be available. ${ }^{22}$ We now take advantage of recently published data on money supply, which, by contrast, allows for a much more detailed quantitative analysis, which can then be cross-checked against historical events. ${ }^{23}$

The picture that results from our exercise shows that, throughout most of the eighteenth century, the Bank's actions during times of warfare did not proceed in parallel to those of the government. Over the eighteenth century, times of war were associated with enormous increases in military expenditure in real terms (Figure 4, where $£$ are corrected for changes in the price level over time) and, through a "ratchet effect", permanent increases in fiscal capacity and government size (O'Brien 1988). ${ }^{24}$ But prior to the 1790 s the actions on the fiscal side of government finance were not mirrored by the Bank of England. ${ }^{25}$ Indeed, up to the 1790 s there is no evidence that the Bank of England expanded banknotes relative to coin supply faster at times of war (Figure 5). ${ }^{26}$ In several periods of war, such as the American revolutionary war period, these stocks actually decreased. This was largely because wars were often associated with financial crises and, before Bagehot's doctrine was firmly established in the nineteenth century, the Bank of England's first and foremost priority was to defend its own position, maintaining adequate reserves to avoid a run. ${ }^{27}$

\footnotetext{
${ }^{22}$ For instance, Roberds and Velde (2014) write that the "Bank's note circulation peaked at $£ 28 m$ in 1814 , more than the gold coined during the recoinage of 1773-79".

${ }^{23}$ The data on money supply comes from Palma (2018a).

${ }^{24}$ In Figure A2 of the appendix we show instead real military spending in per capita terms, and the same basic pattern emerges. Given the importance of military expenses for the government's budget, it is not surprising that the equivalent figure for the size of government looks rather similar as well; see Figures A2 and A3 in the appendix.

${ }_{25}$ Furthermore, the fact that the Bank of England was a private institution meant that profits from seigniorage largely accrued to stockowners rather than the government, so direct monetary finance was not an important source of funds for the government.

${ }^{26}$ Note that there is no contradiction between our Figure 5 and the finding by Lovell (1957) that the Bank of England did not use constant reserve ratios.

${ }^{27}$ Nonetheless, while not systematically, the Bank did engage in Bagehot-type actions earlier on (see for instance, Kynaston 2017, pp. 38, 91 or Kosmetatos 2018).
} 


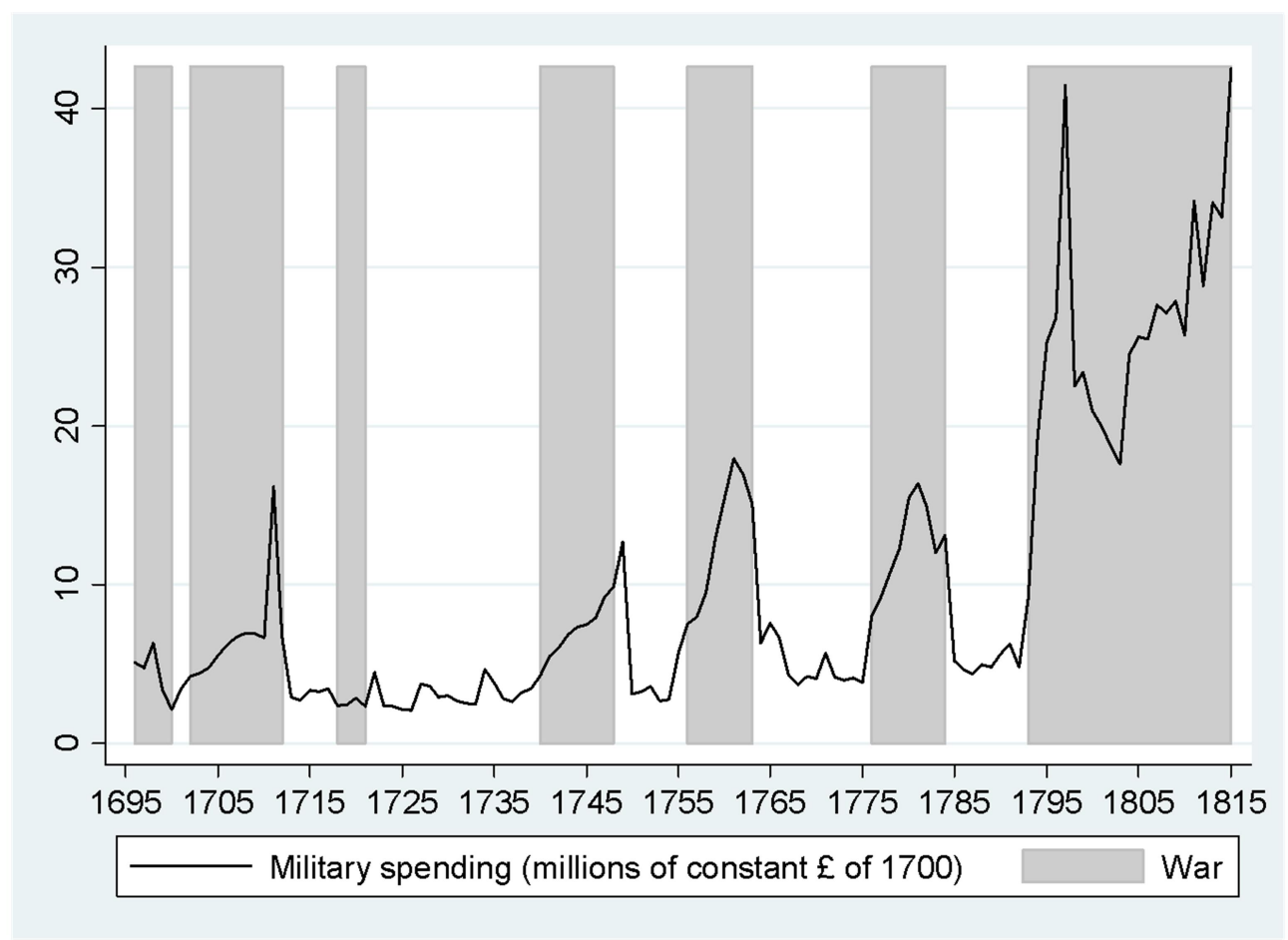

Figure 4. Total military spending 1696-1815, at millions of constant $£$ of 1700 . Total military spending corresponds to spending by the army plus spending by the navy. Naval spending equals total grant plus navy debt plus transport (added from the army), plus funding operations. Army spending equals total grants (grants for army and ordinance services including militia) plus transport (added to the navy) plus funding operations, plus votes of credit, plus subsidies and pay of foreign troops, plus Irish military expenditure (army, ordinance and votes of credit). The shaded areas correspond to years of war. Sources: For naval and military spending, O’Brien and Duran (2010), for the deflator, Broadberry et al (2015).

The data in these figures shows clearly that, unlike what has been shown to be the case for military spending or fiscal capacity, until the 1790 s war had no discernible effect on the growth of paper money supply (which might have increased for fiscal reasons at times of war through lending from the Bank to the Government). Only in the last decade of the century would this change decisively; it was then that in real terms, both notes of the bank of England - and the size of financial intermediation - expanded considerably. ${ }^{28}$ As one authority (who, unlike us, takes a negative view on the extension of the Restriction Period beyond the immediate resolution of the 1797 liquidity problem) writes, "while there was no forcing of the paper issues there was little if any limitation of them" (Feavearyear 1931, p. 178).

${ }^{28}$ It is also the case that provincial banking expanded gradually in the second half of the eighteenth century, and considerably right after 1797 . The direct observable evidence concerns, however, the number of banks, as the issues of each cannot be calculated (Pressnell 1956); see also Joslin (1954). According to Coppetiers (1955), country banks rose from 280 in 1793 to 657 in 1815 and London Banks with privileges to discount at the Bank from 63 in 1792 to 80 in 1814. As the Bullion Committee pointed out, commercial discounts had greatly increased since 1796, and the quantity of country bank notes did so as well. These, it was argued, in practice depended closely on the quantity of Bank of England paper notes in circulation (Feavearyear 1931, p. 183). 


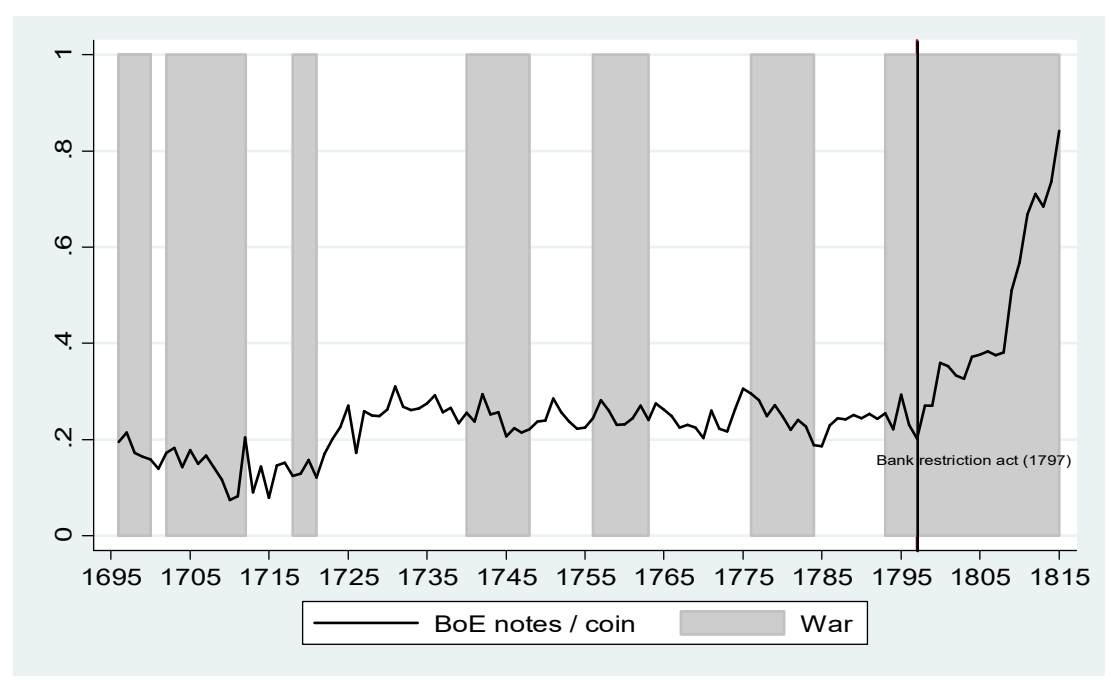

Figure 5. The ratio between Bank of England notes and coin supply, 1694-1815. Grey shaded areas correspond to war periods. Sources: Bank of England (1967), Palma (2018a).

Even in wartime the government did not flood the market with bills and credits delivered from the Bank in the form of discounts. Nonetheless, notes provided the reserves needed not simply to complement bullion but to assist the continued operation of external and internal trade in the adverse circumstances occasioned by warfare. Except for the South Sea Bubble episode (which did not concern the actions of the Bank of England, although it had initially tried to get involved) there were no serious financial crises - at least by the standards of other countries and periods. There was also little crowding out of commercial activity upon which tax revenues depended because both the state and bank behaved prudently in wartime, when pressures to print money invariably intensified. ${ }^{29}$

During both the Great Recoinage (1696) and the Jacobite invasion of 1745, short-lived suspensions of cash payments had been necessary. In both cases convertibility was soon restored, suggesting to the public that suspensions did not last longer than necessary. Decade after decade of good behavior matured to maintain supplies of reserve assets, money and credit in line with the increasing demands of the private economy, and provided creditors with a reserve asset Bank notes - and means of exchange in which they deposited increasing confidence. At the end of a long history of prudence, when demands by the state for both credits and loans intensified to levels never before experienced, the economy was finally well prepared to make a transition to inconvertible paper, which was indispensable for the conduct of more expensive warfare coupled with the continuation of flexible support for the demands of the private economy.

\footnotetext{
${ }^{29}$ Hence Adam Smith's remark that "the stability of the Bank of England is equal to that of the British government" (Smith 2003/1776). Credibility was a two-way street. Furthermore, most public spending complemented private spending, rather than substituting it (O’Brien and Palma 2019).
} 


\subsection{3-1815: extraordinary measures for extraordinary times}

Though the French wars were not completely unanticipated - rearmament had been going on for decades, prior to 1793 or even 1789 (Knight 2013) - their scale and intensity surprised all contemporaries. Compared with earlier conflicts in the century, the wars against revolutionary, and then Napoleonic, France were simply of a different order of magnitude. With the exception of the two twentieth-century world wars, the Napoleonic wars cost more lives in battle than any other modern conflict (Clodfelter 2008, p. 152). ${ }^{30}$ For the British, these wars were something altogether different from earlier conflicts, whether measured by number of battles, military expenditure (Figure 4), or war casualties (Figure 6). Importantly, while previous eighteenth-century wars were fought on the oceans, overseas or in the colonies, the wars of the 1790s-1810s corresponded to a perceived threat to the security of human life and property - certainly that of the aristocracy - in the British Isles themselves.

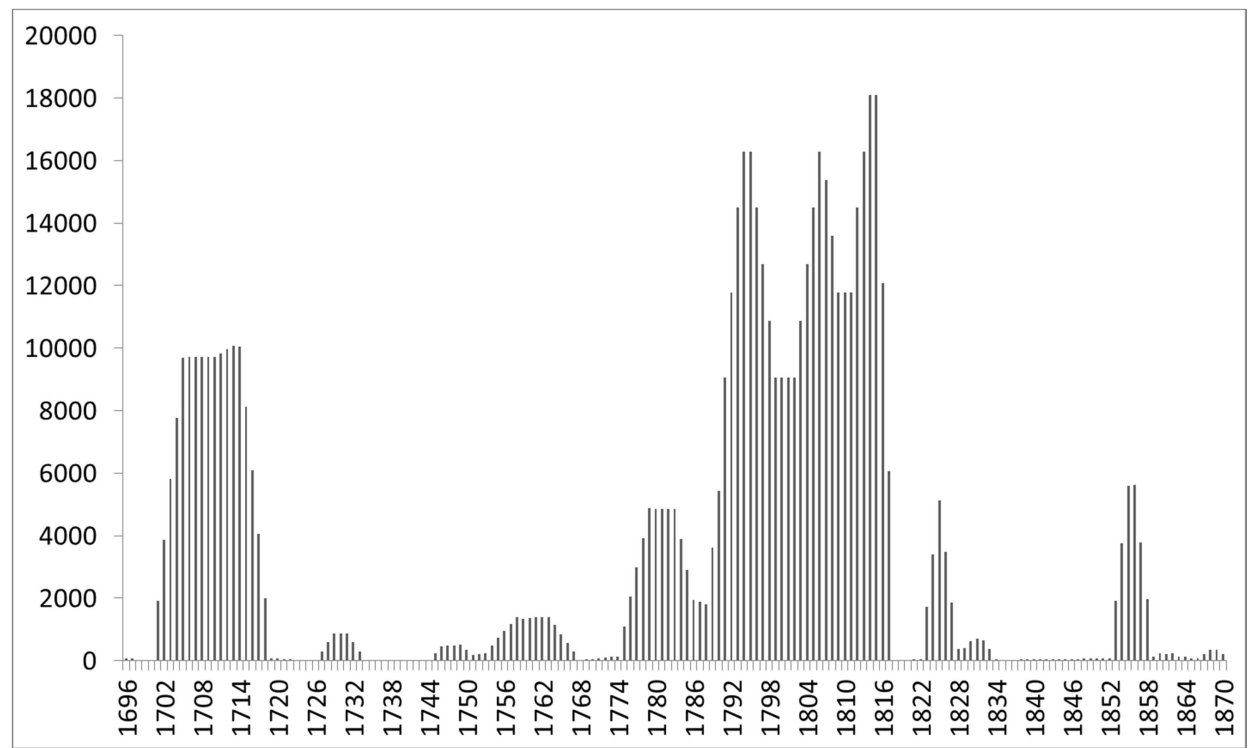

Figure 6. British external conflict war casualties, 1696-1870 (six-year moving average). The unit is number of casualties. Sources: Dincecco and Prado (2012) for 1700-88 and 1816-1870 (which for the latter period rely on the Correlates of War project) and our own series otherwise (see the appendix for details), relying on Clodfelter (2008).

The Bank of England's response did not simply consist of increased lending in the form of a shock or a series of shocks to the money supply, but rather consisted of what in modern terms we might call a change in the systematic component of monetary policy. ${ }^{31}$ The political elites who

\footnotetext{
${ }^{30}$ Additionally, the population was also much smaller in this period than in the twentieth century.

31 As we detail below, this consisted not only in the quick expansion of the Bank's balance sheet (accompanied by a similar trend in provincial banks), but also in the issue of much lower banknote denominations, opening the way to their much more widespread usage; until 1797 bearer notes of less than $£ 5$ issued by any English bank had been more or less illegal (Feavearyear 1931, p. 163).
} 
owned contracts set in nominal terms were willing to tolerate these risky measures because they knew that should the French successfully invade, their properties (and perhaps their lives) were at risk. ${ }^{32}$ As early as 1790 , Edmund Burke was asking the MPs of the House of Commons, in a speech on army estimates, whether they would like "to have their mansions pulled down and pillaged, their persons abused, insulted and destroyed; their title deeds brought out and burned before their faces; and themselves driven to seek refuge in every nation throughout Europe" (Uglow 2014, p. 14).

The arrival of a French fleet to Bantry Bay, Ireland, in December 1796, followed by a French landing in Fishguard, Wales, in February 1797, induced the elites to accept the regime change. ${ }^{33} \mathrm{~A}$ large number of merchants all over the country signed (and publicly announced) declarations in which they promised to accept and keep using banknotes (Kynaston 2017, p. 83). ${ }^{34}$ The most prominent of these meetings was that of London; while the Bank of England had a role in arranging this meeting, ${ }^{35}$ it could not force the merchants to take that decision, which was also announced through publication in The Times. Furthermore, the government continued to accept Bank of England notes for the payment of taxes, in lieu of coin.

The standard account is that although the Directors could legally refuse requests for credit from the Treasury, in practice they had little choice but to accede to the demands of the state (O'Brien 1967, p. 86). There is some truth in this. Outright refusals at critical times could have disrupted military and naval mobilization and no government would tolerate the frustration of its strategic policies by a private corporation for long. The Bank had enjoyed a monopoly as a joint stock bank of issue for continued services to the state and Ministers took good care to make the Bank's privileges subject to periodic review and renewal. ${ }^{36}$ According to this viewpoint, the Directors recognized that they had to obey and always did so.

Indeed, the Director's conflict with the Treasury during the years 1795-97 reveals how their

\footnotetext{
${ }^{32}$ It would be expectable that dropping convertibility could generate some inflation. Even if these fears turned out to be exaggerated, politically influent elites would have feared the erosion of the purchasing power of their nominal revenues. For a related argument which applies to a later period, see Eichengreen (1992), who argues that the interwar gold standard was not dropped earlier, among other reasons, because of the limited political influence of the groups that would gain from inconvertibility and depreciation. But when Pitt promised the Bank in early 1797 that its suspension would be confirmed in Parliament - as it turned out to be - he must have known that support would exist. And given the help that the Bank gave to the government, the Bank's insolvency would have been seen as an outcome to avoid, especially in the wartime circumstances of 1797 and the years that followed.

${ }^{33}$ Other factors were also at play, as discussed in section 2.2.

34. A similar merchant declaration had been made during the brief suspension of 1745 (e.g. Kynaston 2017, p. 35).

${ }_{35}$ The meeting was sponsored by the Bank with no involvement by the government (Shin 2015, p. 424).

${ }^{36}$ Clapham (1944, vol. 1, p. 177) and Committee of the House of Commons on the Bank, Parliamentary Papers (1807, vol. 2, p. 111). See also Broz and Grossman (2004).
} 
power to curtail loans to the government consisted of no more than putting pressure on the Chancellor to borrow more money directly from the London money market. ${ }^{37}$ And it was also the case that after August 1797, the Treasury increased its demands on the Bank to take a contracted amount of Exchequer Bills, and to purchase more on the market, under the understanding that the Bank should not resell them (Clapham 2008b, p. 11).

However, the facts prevent our acceptance of the idea that the Bank of England was always following government orders. The Bank could deliberately ration lending to the government, and in many instances did so (Clapham 2008b, p. 5; Duffy 1982; p. 80, Desan 2014; p. 327). It is true that total securities held by the Bank were highly correlated to Government expenditures minus taxation. The Bank provided the government liquidity pending receipts from taxes and perpetual loans. ${ }^{38}$ But the Government could not simply borrow as much as it wanted. After Suspension the Directors continued to regulate discounts to the private sector on roughly the same rules as before, and from time to time they warned the Treasury that their holdings of Government debt may become excessive and lead to undesirable and unintended consequences for prices and the exchange rate (O'Brien 2000). ${ }^{39}$

We hence identify a problem with interpretations of the Suspension period based on the fiscal theory of the price level, such as Antipa (2016). These explanations impose that faced with future budget deficits, the government would simply choose an arbitrary parity at the time of resumption, or equivalently, monetize the debt. But the Bank of England did not simply follow government orders. There are several reports of episodes when, for instance, "The Bank had informed Mr. Pitt ... that it would be absolutely out of their power to make the ... [advance] of

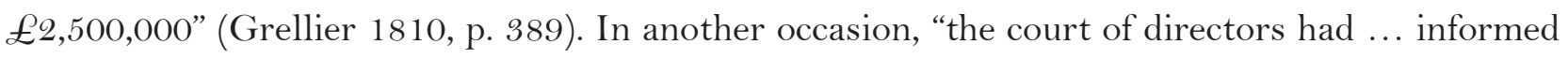
the minister, that they had determined to give orders to their cashiers to refuse payment of all such bills whenever the advance thereon exceeded the sum of $£ 500,000 ”$ (Grellier 1810, p. 390).

\footnotetext{
37 Committee of the House of Commons on Suspension 1797, in Parliamentary Papers (1826, vol. 3, pp. 17, 73, 145, 157 and appendix 9). The monetary history of these three years is also revealing for the light it sheds on the influence exerted by the Bank and the Treasury on the liquidity position of London's money markets. Between 1795 and 1797 the Chancellor of the Exchequer as head of the Treasury attempted to comply with the Directors' pressure to market bonds rather than bills and to issue a higher proportion of bills direct to the capital market. Whenever the Bank exchanged its notes for exchequer and other government bills, subsequent expenditure by the navy, army and other departments of state added to the supply of Bank notes in the hands of the public, who then deposited surplus cash with private bankers. Finding themselves with more reserve currency in their tills bankers then granted additional credit to clients and the money supply and transactions increased.

38 The Bank provided money for the state both directly by monetizing bills and indirectly by helping contractors meet their obligations for payments of loans (bonds).

39 This was the right policy to pursue in wartime. Inflation was moderate and some depreciation of the pound was a price worth paying to support the state engaged in warfare and an export sector attempting to surmount a French and American blockade. The directors vigorously resisted the bullionist notion that they were under state control.
} 
The Bank had a certain level of autonomy and independence, and cared for its own reputation. ${ }^{40}$ Indeed, "Much of the correspondence written and verbal, between Pitt and the Bank ... concerned mainly ... pressure for advances which the Bank so stubbornly resisted” (Clapham 2008a, p. 267). Unlike what the viewpoint of fiscal dominance would suggest (Antipa 2016), the records indicate numerous times when the Bank of England denied lending to the government, or had otherwise its way (Kynaston 2017, pp. 16, 23, 34, 56-7, 79-80).

Hence, we instead propose an alternative interpretation: It was the historical prudence of the Bank with regards to monetary expansion that signaled its independence from the government and hence led to its building-up of credibility capital. This hypothesis is underpinned by recent advances in the literature. For our purposes, it is useful to consider the framework offered by Bordo and Siklos (2015). The authors define a central bank to be credible "when it delivers, subject to a random error, the implied inflation rate objective conditional on the monetary regime in place" (Bordo and Siklos 2015, p. 17). This allows them to quantitatively measure the driving forces of credibility over time. A finding that is important for our paper is that independence is a positive determinant for credibility. As we argued above, the century-long prudent credit policy by the Bank was a strong indicator of its independence. While not yet fully a central bank in the modern sense, and although dependent on charter renewals, the Bank did not simply yield to government demands, as we have shown.

\section{Long-term consequences}

\subsection{Towards a paper money regime}

The consequences of the new regime of paper money would continue to be felt for a long time, despite the establishment of a mixed gold coin standard in 1819-21.41 Once people got used to paper money, the system never went back to the predominantly commodity money, coin-based system which had been in place before the late-eighteenth century. The 1793-1815 wars caused a monetary policy regime shift. The shift was conditioned, and indeed made possible, not just by the military and geo-political circumstances of the last decade of the eighteenth century but also,

\footnotetext{
${ }^{40}$ In 1791, for instance, the Bank of England won a struggle against the government for the control of dividends (Kynaston 2017, pp. 57-8).

${ }_{41}$ We do not refer to the pound during the Restriction as the "paper pound" because we prefer to emphasize its fiat nature, which is how was truly distinguished from the pre-1797 or the 1821-1914 periods (both of also had periods of suspension, albeit rare and short).
} 
importantly, by a prior history of prudent financial management by the Bank as well as the state. The state, while accepting as necessary the Bank's liquidity provision, always refrained from requesting amounts that would lead to problems such as unstable currencies and exchange rates, hyperinflation, and consequently widespread refusals to accept notes and deposits, frequent features of comparable experiments with public banks linked to states on the mainland.

Figure 5 shows that the Bank of England shifted gears in the 1790s, but it would be wrong to assume that after 1821 there was a return to the previous status quo. Figure 7 now extends the horizon of Figure 5 to the mid-nineteenth century, emphasizing the special nature of the Restriction Period. ${ }^{42}$ The figure shows three important facts about this period. First, after a long period of stability, there was a spike in Bank of England notes at the time of the Restriction Period. ${ }^{43}$ Second, when the supply of notes was later reduced, the reversal was only partial: the level did not return that of the 1790s. Third, and crucially, the previously stationary distribution then gained an upward trend - the growth which started in the 1790 s continued into the nineteenth century. The regime change to the system caused by the Bank Restriction in the 1790 s persisted well into the future, long after that act was repealed. As we describe in the next subsection, it caused a permanent shift to a paper-based monetary system, which - despite the later imposition of a gold standard (Redish 1993), and the withdrawal of the smallest denominations (but not $£ 5$ notes; Kynaston 2017, p. 114) - allowed for continuous growth of paper money relative to slower-growing quantities of precious metals well into the nineteenth century. The same overall pattern is found if $\mathrm{M} 2$ is used as the denominator (Figure 10).

\footnotetext{
${ }_{42}$ We stop in 1844 , the moment of Peel's Act, which imposed a $£ 14$ fiduciary limit on the Bank, much against its will. Following this, "the Bank's power over its note issue was ... much reduced" (Kynaston 2017, p. 143). Our ratio indeed falls in the aftermath of the act, but that period goes beyond the scope of our present paper.

${ }^{43}$ If instead of Bank of England notes, a broad measure of money supply (which Palma 2018 calls M2, though it differs a little from modern definitions) is used as the numerator, the ratio stays around 1.5 from 1696 to the $1790 \mathrm{~s}$, then steadily rising until it reaches over 3.5 around 1844).
} 


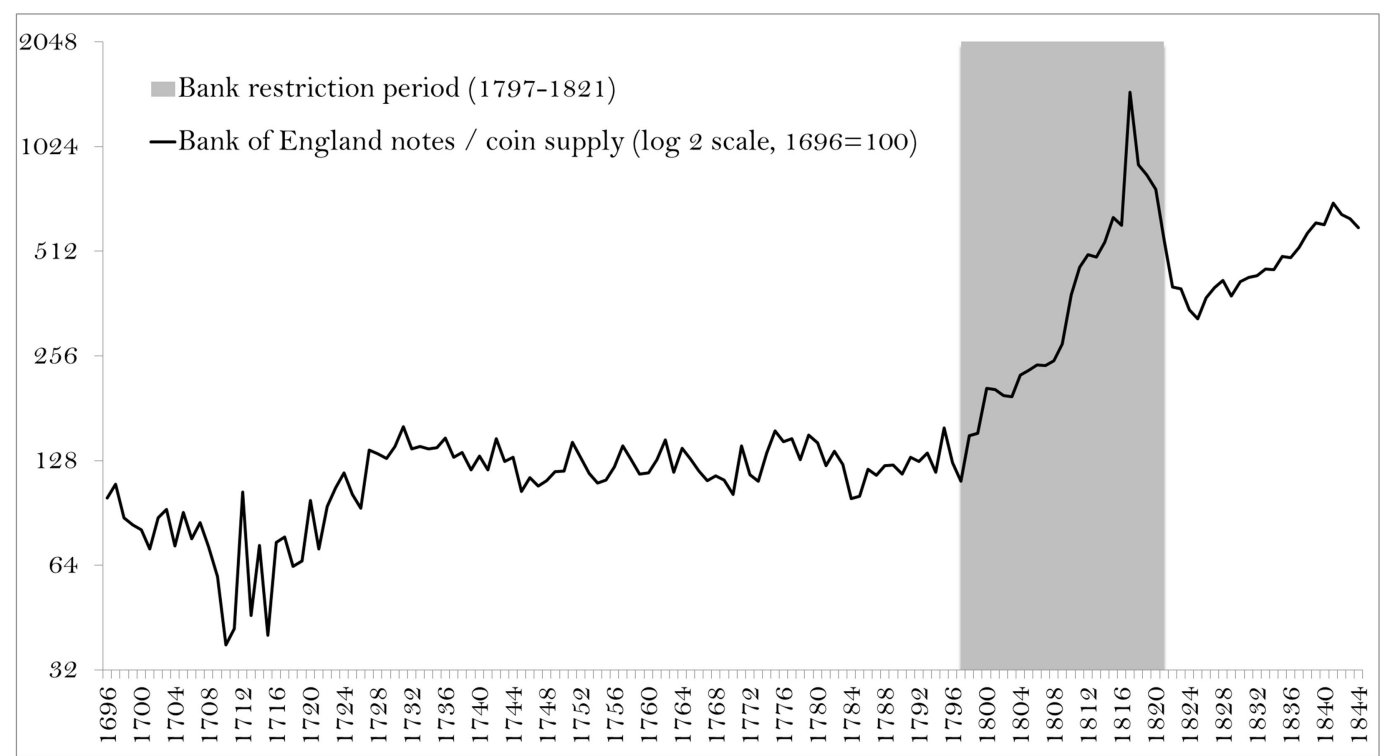

Figure 7. The ratio of Bank of England notes to coin supply, 1696-1844 (log 2 scale, 1696=100). Sources: for banknotes, Bank of England (1967); for coin supply, Palma (2018a).

What our new long-term data (Figures 5 and 7) emphasize is that it was a long history of previous prudence by the Bank of England that allowed for a monetary expansion to occur on this scale without negative consequences in the form of inflation or a significant discount on banknotes being observed. Eventually, when it was ultimately necessary, the Bank and the government abandoned their previous orthodoxy; this move was successful thanks to a century of accumulated reputation for trustworthiness which led the public to believe that the value of the Bank's paper money (and the public securities that backed it) would be honored. ${ }^{44}$ This helps us understand the context behind the pre-Bagehot doctrine mindset of the Bank's directors - by the nineteenth century the Bank was playing a much more central public role than it had before, but there was awareness by its Directors that the success of its policies had been largely due to the long-term accumulation of a reputation for prudence; only very "special times" would justify deviating from such policies. ${ }^{45}$

In this paper's appendix (section A3), we perform a number of statistical tests which demonstrate how 1797 marks a clear historical break. We focus on the ratio of Bank of England notes over coin supply as our dependent variable. We perform structural break tests on this variable, which are likelihood-ratio (or Wald) tests of whether the coefficient of time-series regressions of this variable

${ }_{44}$ This belief was based on the observation of a century of "good behavior" by the Bank and on the public's belief that Britain would ultimately win the war - an outcome towards which the Bank of England's support to the government turned out to be more than incidental as well (O'Brien and Palma 2019).

45 Acworth (1925), Gordon (1976, 1979), Gambles (1996). 
on a time trend is statistically different between periods defined by break dates. Breaks in stationarity ${ }^{46}$ identify periods of important historical change. What the results suggest is that while the period before 1797 was one of remarkable stability, the Restriction Period of 1797-1821 represented a historical discontinuity, and one which would continue to be felt after 1821 as well, when the distribution gained an upward trend (this confirms what can be seen visually in Figure 7). ${ }^{47}$

\subsection{Inflation and the Bank of England}

The credibility of the Bank of England was critical to the success of Suspension. Credibility might have been affected had excessive note-issuing for profit-maximization led to inflation. We argue that despite the accusation of the bullion committee and some other subsequent analysts, the Bank's suspension during 1797-1821 was not been responsible for the observed wartime inflation pattern. ${ }^{48}$

Two reasons allow for this conclusion. First, prices had been slowly rising since the 1760 s, with acceleration noticeable from the late 1780 s (Figure 8). The reasons for this include real-side factors such as the growth of the population (Clark 2001), and after 1793, shortages associated with the war economy, a concentration of bad harvests, disruptions to trade, increased taxes, military subsidies to allies, and the reallocation of resources towards the army and navy. Secondly, prices peaked in 1813 and started falling after that date, after the first bullion committee had been set up but well before convertibility was restored. At that point in time, it was far from certain whether a return to gold would happen at the pre-suspension parity.

The timing of inflation does not match that of the expansion of the Bank's notes. Figures 1, 2 and 5 show the banknote expansion happened immediately in 1797, continuing at an approximately constant rate. This does not coincide with the pattern of inflation, as shown in Figure 8.

\footnotetext{
${ }^{46}$ Our formal tests and discussion are restricted to the notion of weak stationarity.

${ }^{47}$ Some of our econometric tests also cannot reject a structural break in the first quarter of the eighteenth century, but there are three important differences relative to the post-1797 period. First, the statistical evidence in favor a break around 1720 is weaker than is the case for 1797 . Second, the economic magnitude of the break of the first quarter of the century is much smaller too, as is shown in Figures 5 and 7 . More importantly, unlike what happened after 1797, the break was followed by a long period of stability. In other words, there may have been a small upwards shift in the mean of the distribution around 1720, but the distribution did not gain a trend or unit root, unlike what would happen in the late century. By contrast, the Restriction Period of 1797-1821 was a regime shift towards the permanent dominance of paper (though not yet fiat) money during the nineteenth century.

${ }_{48}$ A recent paper claims that "Suspension was accompanied by substantial inflation" (Antipa 2016). The data do not bear this out: inflation per year averaged only 1.1\% during 1797 to 1815 (using the price index of Gayer, Rostow and Schwartz), or $1.3 \%$ per year using the GDP deflator of Broadberry et al (2015). These numbers would be even lower if 1821 was used as an end-date, and are much lower than comparable episodes in France or the United States. Furthermore, during 1797-1821 real aggregate GDP growth averaged 1.5\% per year (Broadberry et al 2015).
} 
Instead, what happened was that payment deficits caused by the war economy caused depreciation of the pound, especially noticeable into the later years of the first decade of the 1800 s (Boyer-Xambeu et al. 1994), as the Continental Blockade and the 1807 American Embargo took effect (Neal 1990). The resulting depreciation of the pound (Neal 1991, p. 64) caused domestic prices to rise and created the need for the Bank of England to supply enough banknotes to keep the money supply from falling (Thornton 1802), especially as this was a period of real GDP growth. ${ }^{49}$

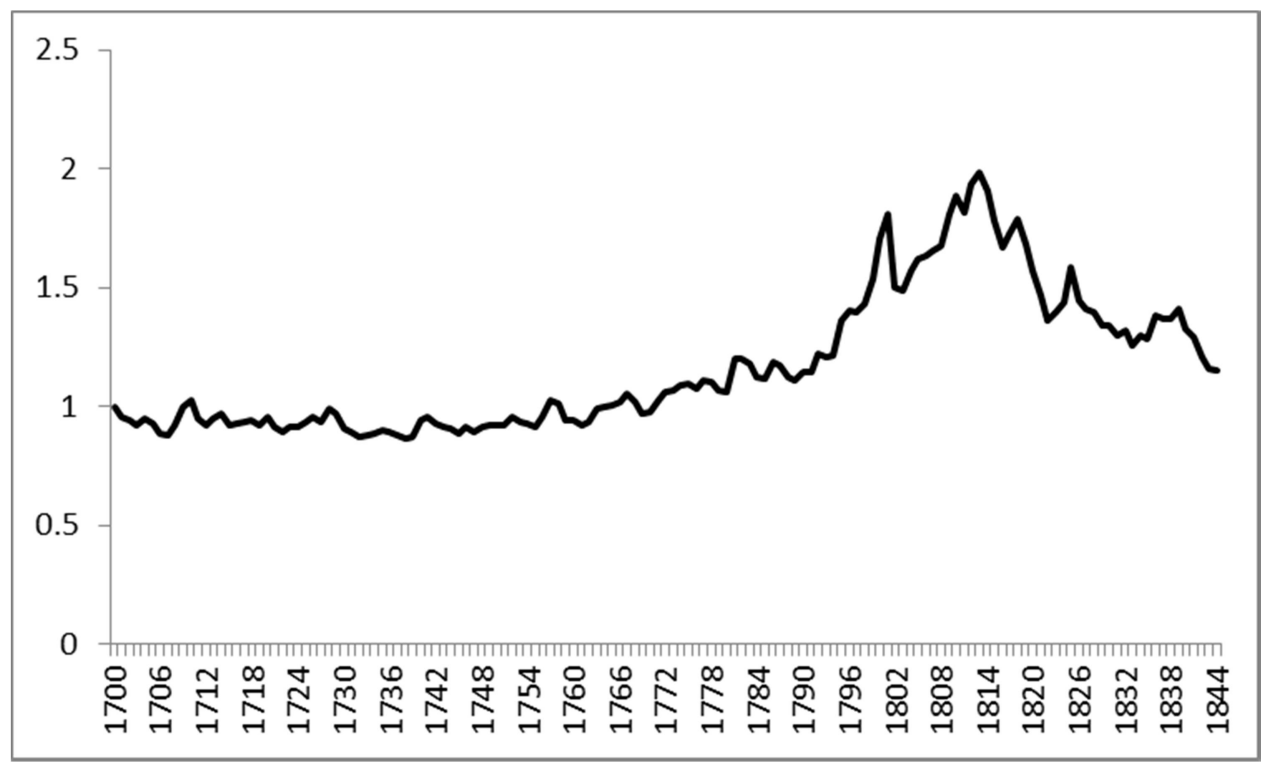

Figure 8. Price level in Britain during 1700-1844, index with 1700=1. Source: Broadberry et al (2015).

It was Parliament which ultimately forced resumption as early as $1819-21.50$ But this does not prove that the Government had been committed to dynamically consistent policies all along while the Bank was not, or that the Bank was just blindly following Government orders. ${ }^{51}$ Furthermore, from a modern perspective, fiat money is a more efficient monetary system. ${ }^{52}$ The stability of a fiat money system requires that the monetary authority is able to credibly commit to a stable inflation rate, but inconvertible banknotes may not have been the main culprit behind wartime inflation, as there was no simple causal chain from the quantity of banknotes in circulation to the price level (Clapham 2008b, pp. 16-9).53

\footnotetext{
49 The compound annual growth rate was $1.5 \%$ during 1797-1815 (Broadberry et al 2015).

50 The Bank was forced in part because of the bullion debate itself (Kynaston 2017, pp. 111-2).

${ }^{51}$ In 1794 it was in fact the Bank director Samuel Thornton who urged Pitt to issue more exchequer bills (Kynaston 2017, p. 78), a situation rather different from what the "fiscal dominance" view (Antipa 2016) would suggest.

${ }^{52}$ The resumption of convertibility at the prewar standard was predated by deflation which continued after 1821 and created difficulties for the transition from a wartime to a peacetime economy (Acworth 1925). It also led to "speculative ventures in the capital markets, and the eventual collapse of the financial system ... followed by widespread bankruptcies and unemployment” (Neal 1998, p. 53). Neal takes a more positive view of its long-term consequences. ${ }^{53}$ Indeed, some wartime inflation peaks "cannot be connected at all closely with the mere quantity of notes in circulation" (Clapham 2008b, p. 9).
} 
Inflation as well as the market price of gold fell considerably once the war was over, as markets opened, the balance of payments adjusted, and the war drain ended (Clapham 2008b, p. 37). It had not been the case that the Bank had wanted Suspension to continue indefinitely; despite the fact that inconvertibility was rather profitable for the Bank, as early as October 1797 the Bank had wanted to resume payments. ${ }^{54}$ But by $1808-9$, both the Bank and the City - worried about the effects of illiquidity, deflation, and a strong exchange rate - wanted suspension to continue. In the end, it was the politicians that triumphed.

Ultimately, even if some inflation did result from the Bank's actions, it may have been optimal. As Clapham (2008b, p. 32) writes: "No one said frankly - accept a measure of inflation for victory's sake". Overall, there is no evidence to conclude that the Bank followed irresponsible policies. As Duffy (1982, p. 81) concludes, "the Bank's awareness of the need to regulate discounts did not fall into abeyance during the Restriction”.

\subsection{Unintended long-term consequences}

The long-term consequences of the Restriction Period were profound at several levels. In the words of Clapham, "Englishmen of rank and file - wage earners and small traders - knew little of paper money, and in the early years of suspension they had learnt its use only gradually" (Clapham 2008a, p. 162).55 It was with, and indeed because of, the 1790-1810s wars and the Restriction Period that most people learned to use, and got comfortable with using, banknotes. While up to the $1790 \mathrm{f} £ 10$ notes were the lowest note denomination issued by the Bank of England (over $£ 1,000$ in 2015 prices), it was only in 1793, at the start of the war against Napoleonic France, that $£ 5$ notes were first issued. ${ }^{56}$

Denominations of $£ 5$ were in turn followed by $£_{2}$ and $£ 1$ banknotes, issued within a week of Suspension in 1797 (Desan 2014, p. 401). Crucially, also allowing for a margin of contemporaneous inflation, $\mathfrak{1}_{1}$ was then just enough to pay a laborer's weekly wage (Schwarz

\footnotetext{
${ }^{54}$ Pitt had not allowed this, despite the Bank's reserves having largely recovered by then; see Clapham (2008b, p. 4). ${ }_{55}$ Clapham (2008b, pp. 2-3), also writes that "As gold became scarcer the $£ 1$ and $£ 2$ notes were used more and more for wage-paying and retail trade”. Kynaston (2017, p. 88) concurs, writing that this small-denomination policy put "banknotes in the hands of the general populace for the first time".

${ }_{56}$ By contrast, payments through the Bank of Amsterdam (which did not issue circulating notes) were even larger than $£ 10$ and exclusively wholesale (Quinn and Roberds 2016, p. 70). £10 in 1793 corresponds to $£ 1,058$ in 2015 prices (Officer and Williamson 2016b). The modal denomination of Bank of England notes prior to suspension in 1797 had been £20 (Hotson 2012, p. 12).
} 
1985). ${ }^{57}$ A study of pickpocketing cases in the Old Bailey covering the periods 1735-1750, 176580 and $1795-1810$, shows that in the earlier periods small numbers of high value notes were stolen while in the last period larger numbers of low value notes were taken (Dolan 2011). Finally, a recent study by Shin (2016) of 10,000 lost note claims in the Lost Note Book held by the Bank of England Archives shows that while before Suspension Bank of England notes were mainly centered in London, after 1797 an increasing number of claims came from English provinces. Furthermore, claims from Plymouth and Portsmouth, navy and port towns, increased dramatically, showing that navy staff payments had significant impact in inducing the spread of the notes. Finally, after 1797 there was a large increase in claimants from the retail trade, which proves that notes appeared much more frequently in everyday transactions.

Hence, despite the Suspension and dramatic expansion of banknotes, Bank of England notes were accepted by the public and began to be used not only as a store or value or at the retail level, but also, for the first time, as a means of exchange for ordinary people. Bank of England notes became legal tender through an 1811 act of Parliament, but they had been de-facto legal tender since the Bank Restriction Act of May 1797. ${ }^{58}$ Furthermore, the Bank of England's expansion encouraged provincial banks (which held reserves at the Bank) to expand their issues as well. ${ }^{59}$ The increased interest of the public in the usage of banknotes is suggested by the fact that written references to banknotes spiked at the time of suspension, and interest in them continued thereafter (Figure 9). In the words of Shin (2015, p. 418), "the experience of paper money had a profound impact upon the popular notion of money".

Once people got used to using paper money there was no going back. Despite the adoption of a mixed gold standard in 1821, banknotes continued their steady rise as a percentage of the total money supply into the nineteenth century (Figure 10). The age of commodity-money as a dominant form of payment was over. For the state, a more monetized economy was also easier to tax, further encouraging a positive loop between monetization and state capacity (Capie 2004, Palma 2018b, O’Brien and Palma 2019). As the nineteenth century advanced and the process of

\footnotetext{
57 The Government was understandably concerned with counterfeits and stiff penalties - execution (or under mitigating circumstances, transportation) - were promised for "uttering false bank notes". This was enforced: for instance in 1817, there were 32 capital convictions, 95 other convictions "for having forged Bank Notes in Possession", while only 15 people were acquitted. (House of Commons Papers, Volume 16, p. 222, in Parliamentary Papers 1818). ${ }^{58}$ For a recent review, see Chadha and Newby (2013, pp. 11-2). For the legislation passed by Parliament in defense of Bank of England notes, see Desan (2014, p. 407).

59 The number of country banks rose from 280 in 1793 to 657 in 1815 . The London Banks with privileges to discount at the Bank rose from 63 in 1792 to 80 in 1814. This was accompanied by dramatic expansion of the balance sheet of provincial (and London) banking after 1797 (Pressnell 1956, Joslin, 1954, Coppetiers 1955).
} 
modern economic growth started to take place, increased monetization may have helped attenuate deflationary pressures.

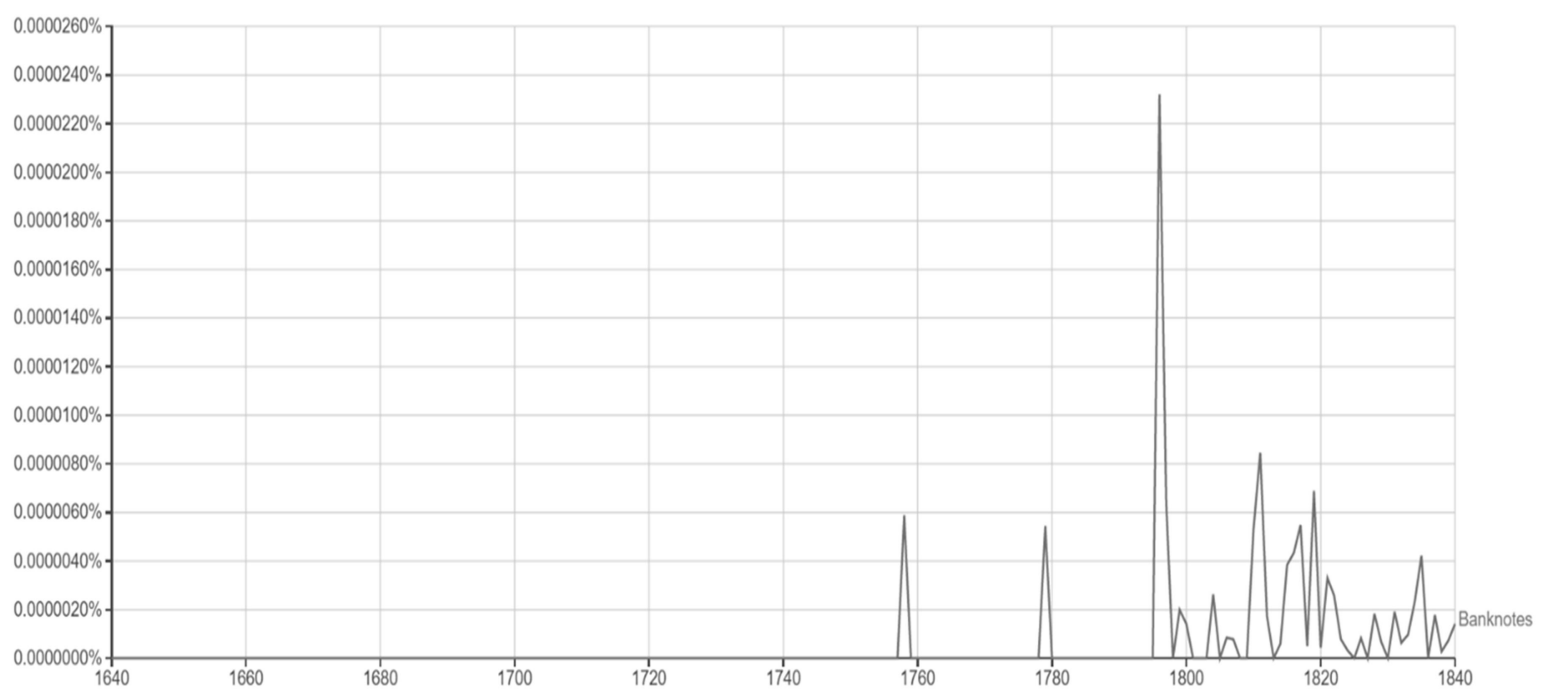

Figure 9. Google Ngram viewer for "Banknotes", from the corpus of "English", for the period 1650-1840 (with zero smoothing). The unit is: percentage of total written references for each year.

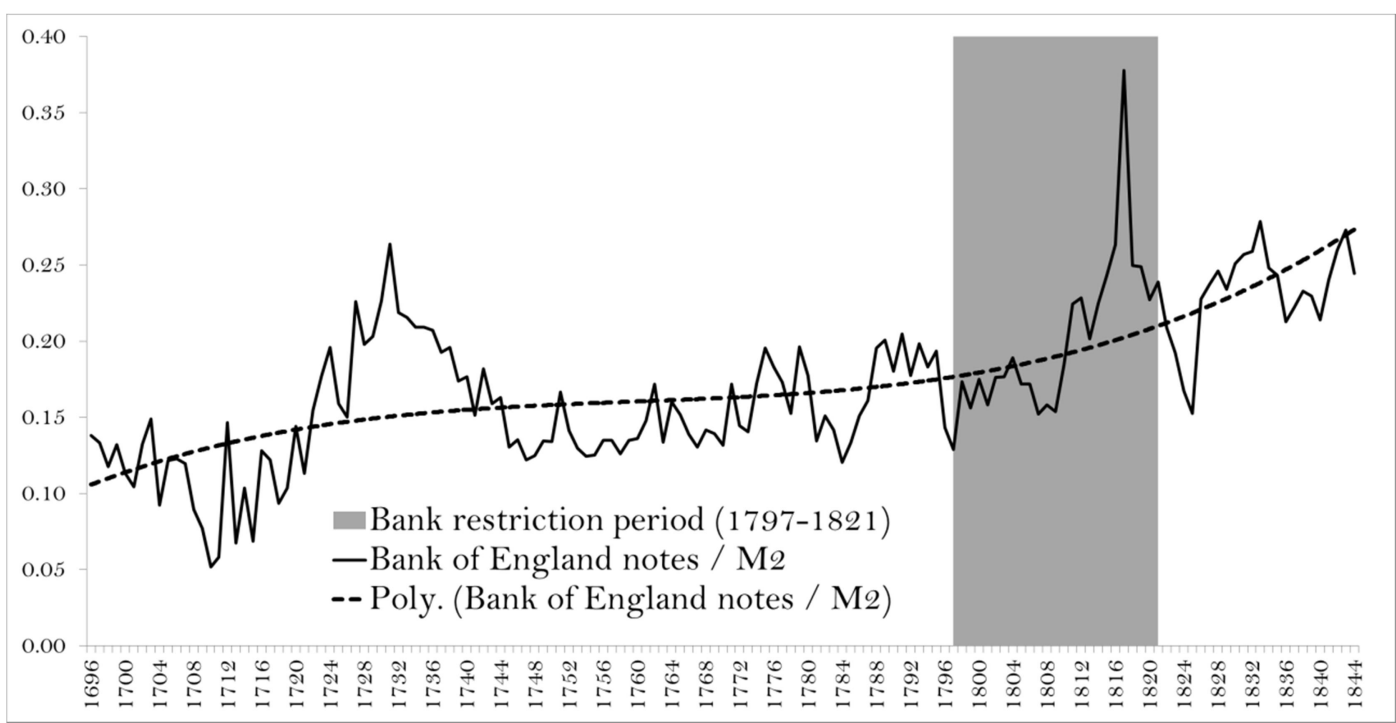

Figure 10. The ratio of Bank of England notes to M2, 1696-1844. Sources: for banknotes, Bank of England (1967); for M2, Palma (2018a). The dashed line fits a $3^{\text {rd }}$ degree polynomial.

Once paper money became the dominant means of payment, coin never regained its prominence. Furthermore, while convertibility was restored in 1821, and Peel's Act of 1844 (predated by Palmer's rule) curtailed the liberties of the Bank in terms of issuing paper money, the restriction that the Bank's issues had to be fully backed (or partially so after Palmer's rule) was less of a constraint to the growth of paper money than it may at first appear. Firstly, reserves could be in the form of either bullion or public securities (including deposits), and the latter were available elastically. And secondly, convertibility could be again dropped as needed. Faced with a real shock the Bank of England 
temporarily suspended Peel's act as early as 1847 , and issued fiat money without being constrained to having full gold backing (Dornbusch and Frenkel 1984).

\section{Conclusion}

The Restriction was associated with one of the first successful transitions to a fiat money system for a major economy. ${ }^{60}$ Despite the eventual return to convertibility in 1821 , coin supply never regained its previously central role in money supply: the age of the banknote had begun. Britain's regime shift to paper money was mechanically implemented through the Bank Restriction Act but it was the result of two distinct causes. Over the short run, it resulted from the unusually dangerous military circumstances of the last decade of the century, combined with increased pressure from France's return to a commodity-money system. These reasons have been emphasized before in the literature, and we agree that they mattered. But alone, they would have not sufficed for the policy's success. The public would not have accepted money if it anticipated loss of value. ${ }^{61}$ It was the reputation of the Bank, accumulated over a century of prudence, which interacted with that of the state to make the actions and promises of both credible during the Restriction. ${ }^{62}$

Our data from 1698 to 1821 suggests that the Bank never became an agency of the state, even in wartime. ${ }^{63}$ Over time the Bank built up a reputation for prudence. Thus when the constraint imposed by convertibility was removed the public could rely on the Directors of this private corporation - whose shareholders would expect them to maximize profits - to maintain the established, prudential and traditional rules and conventions for both loans to the state and discounts for its clients. At the time the Directors and Ministers made this very point when confronting attacks that the Bank was "forcing" notes into circulation. They were correct.

\footnotetext{
${ }^{60} \mathrm{We}$ are here using the term fiat money as intrinsically worthless, unbacked paper with positive market value. Other fiat money systems remained partial and limited to peripheral regions (as in Scotland or North America) or eventually failed (as in medieval China or eighteenth-century France). However, Sweden's Riksbank banknotes were inconvertible since 1745 , and had "by the middle of the eighteenth century, become an essential if not predominant component of the Swedish monetary environment" (Roberds and Velde 2016). See also Quinn and Roberds (2016) for the case of the Dutch Republic. ${ }^{61}$ In France, paper money was only held as long as the Terror lasted: it was a guillotine-enforced system (Sargent and Velde 1995). This strongly contrasts with Britain's experience, where "inconvertible paper money was grounded less in coercion ... and more on ... trust" (Shin 2015, p. 419).

62 This trust was reflected in the declaration movement whereby mostly merchants, but also people such as "farmers, grocers, inn-holders, butchers, bakers" (Shin 2015, p. 430) signed regional declarations, publicly promising to accept and keep using banknotes for payment. In the case of the London declaration, there were signatures by many "drapers ... warehousemen ... haberdashers ... stationers ... sugar refiners ... brewers ... ironmongers” (Shin 2015, p. 431). The declarations were targeted at a wide audience, and specifically, the lower classes (Shin 2015, p. 429).

${ }^{63}$ Nevertheless, as we documented, the Bank did provide high levels of support to the Government during the Restriction Period.
} 
Wartime military pressures also mattered, and interacted with the reputation of the Bank and the state. The extraordinary danger that the external war against France and its allies represented called for, and allowed, much bolder monetary policy experiments than would otherwise have been possible to implement. ${ }^{64}$ They would not have been possible in "normal" times in Britain (including at previous times of warfare), but they were also not possible in continental countries where institutions of comparable reputation to the Bank of England did not exist. At the beginning of these unusually serious wars, for practical purposes it may have seemed impossible for people in Britain to estimate the probability of future outcomes, such as winning the war or being invaded. ${ }^{65}$ Well-informed contemporaneous observers knew well that the outcome of the war was far from certain (Knight 2013). The pessimist's view of Britain's chances of prevailing was suggested by the political cartoonist James Gillray when he depicted French alarmists urging John Bull, representing the English public, not to accept paper money; the suggested reasoning was that once the French landed, Bank of England notes would surely be worthless. But he had to concede that the public accepted it. ${ }^{6}$

Despite the seriousness of the military threats, and the unprecedented injection of liquidity in the economy which we have documented here, no major panic ensued, and inflation remained moderate when compared both with that in other countries at the time, and with the next war-time suspension, World War I. As the evidence we discussed in this paper suggests, the British public accepted the Bank's fiat - essentially government debt repackaged as money - at a moderate discount, certainly by continental standards. ${ }^{67}$ While some inflation did occur, possibly in part as a consequence of the very aggressive monetary policy pursued by the Bank, Britain won the war and, importantly, by the time normal conditions returned the credibility of the Bank had not been compromised. By showing a willingness to be pragmatic during unusual times, the government and the bank may have in fact reinforced the public's confidence in the financial system. ${ }^{68}$ We have here emphasized that in order for this to be possible, the government's credible commitment was not enough. In order for Britain to withstand the test of the French revolutionary and Napoleonic wars, the Bank of England's patiently

\footnotetext{
${ }^{64}$ Bordo and Kydland (1995) interpret the gold standard as a contingent rule, in the sense that temporary suspension was possible during an emergency, such as a war, but it would be expected that once that emergency was over, convertibility would be restored at the original parity. But repeated suspensions would not be credible, especially if lasting for a long period.

${ }_{65}$ This is known as a situation of ambiguity or Knightian uncertainty. For a contrary view, see Antipa (2016).

${ }^{66}$ See, in our appendix, Figure A4.

${ }^{67}$ This is not to say that the Restriction Period transition was immediately accepted by everyone (Shin 2015). But while the banknote discount could be up to $50 \%$ (though it was usually less), it must also be recognized that it was only for large-scale transactions that a discount took place: "In the ordinary occurrences of life, and in small transactions ... [notes and coin] might serve as well as the other" (The Times 1811).

${ }_{68}$ The Restriction period permitted the ongoing solvency of the Bank of England (Chadha and Newby 2013), with implications for the financial stability of the country as a whole. See also Newby (2012).
} 
built up reputation among the public through its prudent money management over time was also required.

What factors interacted with the Bank of England's initial reputation to make the policy a success? Three reasons stand out. First, the Bank of England's expansion of banknotes during the Restriction was of a much smaller magnitude than had been the case in France a few years before. In 1797, the ratio of Bank of England notes over nominal GDP was just under 23\%, and in the next few years issues were never such that the $20 \%$ percent mark was crossed again, a target made easier by the economic growth performance of the British economy during those years (Bank of England 1967, Broadberry et al 2015). This strongly contrasts with the case of France during the assignats debacle, where the expansion of fiat was eventually exponential (Sargent and Velde 1995). In contrast with France, the Bank of England's policies were subject to a series of checks and balances, being closely monitored, as exemplified by the "Bullion report", and related controversies and debates (see for instance Feavearyear 1931, pp. 190-2). ${ }^{69}$ Second, not only did Britain already have a comparatively high level of fiscal capacity, being able to credibly borrow, ${ }^{70}$ but the policies of the Bank were also at this time accompanied by a series of fiscal reforms. Two examples were the increase in the land tax, followed by the introduction of an income tax in 1798, which complemented the monetary reforms and allowed for the sustainability of the government's budget constraint, while ruling out hyperinflation. ${ }^{71}$ Finally, the policy was promised (and apparently believed) to be a temporary, wartime measure.

\footnotetext{
69 The Bullion Report wanted convertibility to be restored at the original parity. There is a debate on whether the Bank discounted too liberally in 1808-9 (especially to the commercial sector, rather than the government); see for instance Duffy (1982). It is nonetheless not clear that the 1810 financial crisis and inflation was due to too many banknotes in circulation. It may even have been that the "very issue of [the Bullion] Report, followed as it was almost at once by the failure of several 'several houses of first respectability', had made bankers tighten the purse strings and had forced still more borrowers on to the Bank” (Clapham 2008b, p. 29).

${ }^{70}$ Sussman and Yafeh (2006) illustrate the long process of rendering public finances credible before the French Wars.

${ }^{71}$ For the introduction of the income tax, see O'Brien (2011). For the well-known interdependence between the general price level and the government's finances, see Sargent and Wallace (1981), and Sims (1994).
} 


\section{References}

\section{Primary Sources}

Parliamentary Papers, 1810, 1818, 1826, 1831-32, British Library

\section{$\underline{\text { Secondary Sources }}$}

ACWORTH, A.W. (1925). Financial Reconstruction in England, 1815-22. London: P.S. King \& Son.

ANTIPA, P. (2016). How Fiscal Policy Affects Prices: Britain's First Experience with Paper Money. Journal of Economic History 76(4), pp. 1044-77.

ASHTON, T. (1953). The bill of Exchange and private banks in Lancashire, 1790-1830. In T.S. Ashton and R.S. Sayers (eds), Papers in English Monetary History, Oxford: Clarendon Press, pp. $37-49$.

BAI, J. and PERRON, P. (1998). Estimating and testing linear models with multiple structural changes. Econometrica 66(1), pp. 47-78.

BANK OF ENGLAND (1967). Bank of England Liabilities and Assets: 1696 to 1966. Quarterly Bulletin, June edition. Available at

http://www.bankofengland.co.uk/archive/Documents/historicpubs/qb/1967/qb67q2appendix 1591 63.pdf, Accessed August 13, 2014.

BORDO, M.D. and WHITE, E.N. (1991). A tale of two currencies: British and French finance during the Napoleonic Wars. The Journal of Economic History 51(2), pp. 303-16.

BORDO, M. and KYDLAND, F. (1995). The Gold Standard as a Rule: An Essay in Exploration. Explorations in Economic History 32, pp. 423-64.

BORDO, M. and REDISH, A. (1993). Maximizing Seignorage Revenue during Temporary Suspension of Convertibility: A Note. Oxford Economic Papers 45(1), 157-68.

BORDO, M. and SIKLOS, P.L. (2015). Central Bank Credibility: An Historical and Quantitative Exploration. NBER Working Paper 20824. 
BOYER-XAMBEU, M-T. GILLARD, L. and DELEPLACE, G. (1994). Régimes monétaires, points d'or et serpent bimétallique de 1770 à 1870. Revue économique 45(5), 1139-74.

BROADBERRY, S., CAMPBELl, B.M.S., KLEIN, A., OVERTON, M., and VAN LEEUWEN, B. (2015). British Economic Growth, 1270-1870. Cambridge: Cambridge University Press.

BROZ, J.L. and GROSSMAN, R.S. (2004). Paying for privilege: the political economy of Bank of England charters, 1694-1844. Explorations in Economic History 41, pp. 48-72.

CAMERON, R. (1967). England, 1750-1844. In R. Cameron (ed), Banking in the Early Stages of Industrialization: A Study in Comparative Economic History, New York: Oxford University Press, pp. 15-59.

CAPIE, F. (2004). Money and economic development in England. In L.P. de la Escosura (ed), Exceptionalim and industrialization: Britain and its European rivals, 1688-1815, Cambridge: Cambridge University Press

CHADHA, J.S. and NEWBY, E. (2013). Midas, transmuting all, into paper: the Bank of England and the Banque de France during the Napoleonic Wars. Cambridge Working Papers in Economics 1330.

CHALLIS, C.E. (1992). Lord Hastings to the great silver recoinage 1464-1699. In C.E. Challis (ed), New History of the Royal Mint, University of Cambridge Press, pp. 179-397.

CLAPHAM, J. (2008a). The Bank of England: A History. Volume 1: Cambridge University Press. Paperback reprint of the 1944 edition.

CLAPHAM, J. (2008b). The Bank of England: A History. Volume 2: Cambridge University Press. Paperback reprint of the 1944 edition.

CLARK, G. (2001). Debt, Deficits, and Crowding Out: England, 1727-1840. European Review of Economic History 5(3), pp. 403-36.

CLODFELTER, M. (2008). Warfare and Armed Conflicts: A Statistical Reference to Casualty and Other Figures 1494-2007. Jefferson, NC: McFarland.

COPPIETERS, Emmanuel. English Bank Note Circulation, 1694-1954. The Hague: Martinus Nijhoff, 1955. 
COFFMAN, D'M., LEONARD, A. and NEAL, L. (eds) (2013). Questioning Credible Commitment Perspectives on the Rise of Financial Capitalism. Cambridge: Cambridge University Press.

DESAN, C. (2014). Making money: coin, currency, and the coming of capitalism. Oxford: Oxford University Press.

DINCECCO, M. and PRADO, M. (2012). Warfare, Fiscal Capacity, and Performance. Journal of Economic Growth 17(3), pp. 171-203.

DOLAN, A. (2011). Prying in Pockets: relationships between men's clothes and the safety of valuables 1735-1810. The Association of Dress Historians New Research Day, London

DORNBUSCH, R. and FRENKEL, J. (1984). The Gold Standard and the Bank of England in the Crisis of 1847. In M.D. Bordo and A.J. Schwartz (eds), A Retrospective on the Classical Gold Standard, 1821-1931, Chicago, London: University of Chicago Press, pp. 23-120.

DUFFY, I. (1982). The Discount Policy of the Bank of England during the Suspension of Cash Payments, 1797-1821. The Economic History Review 35(1), pp. 67-82.

EICHENGREEN, B. (1992). Golden fetters: the gold standard and the Great Depression, 1919-1939. Oxford: Oxford University Press.

FEAVEARYEAR, A. (1931). Pound Sterling: A History of English Money. 2nd edition, Oxford: Clarendon Press, 1963.

GAMBLES, A. (1996). The Boundaries of Political Economy: Tory Economic Arguments, 1809-47. London:

GAYER, A., ROSTOW, W.W., and SCHWARTZ, A. (1953). The Growth and Fluctuation of the British Economy 1790-1850, 2 Volumes. Oxford: Oxford University Press.

GELDERBLOM, O. and JONKER, J. (2015). Enter the ghost: cashless payments in the Early Modern Low Countries, 1500-1800. CGEH Working Paper Series.

GORDON, B. (1976). Political Economy in Parliament, 1819-23. New York: Macmillan. 
GORDON, B. (1979). Economic Doctrine and Tory Liberalism, 1824-30. London: Palgrave Macmillan.

GRELLIER, J.J. (1810). The history of the national debt, from the revolution in 1688 to the beginning of the year 1800: with a preliminary account of the debts contracted previous to that era. London: *.

T'HART, M., JONKER, J. and VAN ZANDEN, J.L. (1997). A financial history of the Netherlands. Cambridge: Cambridge University Press.

HORSEFIELD, J.K. (1977). The beginnings of paper money in England. Journal of European Economic History 6(1), pp. 117-32.

HOTSON, A. (2012). Stabilizing monetary systems: sterling's currency and credit markets from the $12^{\text {th }}$ to the $21^{\text {st }}$ century. Cambridge Working Papers in Economic and Social History.

JONKER, J. (1996). Merchants, Bankers, Middlemen: The Amsterdam Money Market during the First Half of the 19th century. Amsterdam: NEHA.

JOSLIN, D. (1954). London Private Bankers. Economic History Review, reprinted in J. Pressnell, Studies in the Industrial Revolution (original edition, 1960).

KOSMETATOS, P. (2018). Last resort lending before Henry Thornton? The Bank of England's role in containing the 1763 and 1772-1773 British credit crises. European Review of Economic History, pp. 1-30.

KYNASTON, D. (2017). Till Time's Last Sand: A History of the Bank of England 1694-2013. London: Bloomsbury Publishing.

KNIGHT, R. (2013). Britain against Napoleon: The Organization of Victory, 1793-1815. London: Penguin.

MATHIAS, P. (2004). Official and Unofficial Money in the Eighteenth Century. The British Numismatic Journal 74, pp. 68-83.

MAYHEW, N. (2013). Prices in England 1170-1750. Past and Present $219(1)$, pp. 3-39.

NEAL, L. (1990). The Rise of Financial Capitalism: International Capital Markets in the Age of Reason 
Cambridge MA: Cambridge University Press.

NEAL, L. (1991). A tale of two revolutions: international capital flows 1789-1819. Bulletin of Economic Research 43(1), pp. 57-92.

NEAL, L. (1998). The financial crisis of 1825 and the restructuring of the British financial system. Federal Reserve Bank of St. Louis Review $\mathbf{8 0}(3)$

NEWBY, E. (2012). The suspension of the gold standard as sustainable monetary policy. Journal of Economic Dynamics and Control 36(10), pp. 1498-519.

O'BRIEN, P. K. (1967). Government revenue, 1793-1815: a study in fiscal and financial policy in the wars against France. Doctoral dissertation, University of Oxford

O'BRIEN, P.K. (1988). The political economy of British taxation, 1660-1815. The Economic History Review 41, pp. 1-32.

O’BRIEN, P.K. (2000). Merchants and Bankers as Patriots or Speculators: Foreign commerce and monetary policy in wartime, 1793-1815. In J. McCusker and K. Morgan (eds), The Early Modern Atlantic Economy, Cambridge: Cambridge University Press, pp. 250-77.

O'BRIEN, P.K. (2011). The nature and historical evolution of an exceptional fiscal state and its possible significance for the precocious commercialization and industrialization of the British economy from Cromwell to Nelson. The Economic History Review 64(2), pp. 408-46.

O'BRIEN, P.K. and DURAN, X. (2010). Total Factor Productivity for the Royal Navy from Victory at Texal (1653) to Triumph at Trafalgar (1805). In R. Unger (ed), Shipping and Economic Growth, 1350-1800, Leiden: Brill, pp. 279-308.

O’BRIEN, P.K. and PALMA, N. (2019). Not an Ordinary Bank but a Great Engine of State: The Bank of England and the British Economy, 1694-1821. Unpublished manuscript.

LOVELL, M. (1957). The Role of the Bank of England as a Lender of Last Resort. Explorations in Entrepreneurial History 10, pp. 166-89.

OFFICER, L.H. and WILliAMSON, S.H. (2016a). The Price of Gold, 1257 - Present. MeasuringWorth website, https://measuringworth.com/gold/, last accessed January 2016. 
OFFICER, L.H. and WILLIAMSON, S.H. (2016b). Five Ways to Compute the Relative Value of a UK Pound Amount, 1270 to Present. MeasuringWorth website, https://www.measuringworth.com/ukcompare/index.php, last accessed January 2016.

PALMA, N. (2018a). Reconstruction of money supply over the long-run: the case of England, 1270-1870. Economic History Review 71(2), pp. 373-92.

PALMA, N. (2018b). Money and modernization in early modern England. Financial History Review 25(3), pp. 231-61.

PRESSNELL, L.S. (1956). Country Banking in the Industrial Revolution. Oxford: Clarendon Press.

QUINN, S. and ROBERDS, W. (2016). Death of a Reserve Currency. International Journal of Central Banking 12 (4), pp. 63-103

REDISH, A. (1993). Anchors Aweight: The transition from Commodity Money to Fiat Money in Western Economies. The Canadian Journal of Economics 26, pp. 777-95.

REDISH, A. (2000). Bimetallism: An economic and historical analysis. Cambridge: Cambridge University Press.

RICARDO, D. (1951/1811). High Price of Bullion, in P. Sraffa (ed), Works 3

ROBERDS, W. and VELDE, F.R. (2016). Early Public Banks II: Banks of Issue. In D. Fox and W. Ernst (eds), Money in the Western Legal Tradition: Middle Ages to Bretton Woods, Oxford: Oxford University Press, pp. 465-88.

SARGENT, T. and VELDE, F.R. (1995). Macroeconomic features of the French Revolution, Journal of Political Economy 103(3), pp. 474-518.

SARGENT, T. and WALLACE, N. (1981). Some Unpleasant Monetarist Arithmetic. Federal Reserve Bank of Minneapolis Quarterly Review 5(3), pp. 1-17.

SCHUMPETER, J.A. (1987/1954). History of Economic Analysis. London: Routledge.

SCHWARZ, L.D. (1985). The Standard of Living in the Long Run: London, 1700-1860. The Economic History Review 38(1), pp. 24-41. 
SHIN, H. (2015). Paper Money, the Nation, and the Suspension of Cash Payments in 1797. Historical Journal 58(2), pp. 415-42.

SHIN, H. (2016). Early users of paper currency: Evidence from the Bank of England Note, 1720s-1820s. Presented at the Economic History Society Conference;

http://www.ehs.org.uk/press/early-users-of-paper-currency-evidence-from-the-bank-ofengland-note-1720s-1820s

SIMS, C.A. (1994). A simple model for study of the determination of the price level and the interaction of monetary and fiscal policy. Economic Theory 4(3), pp. 381-99.

SMITH, A. (2003/1776). The Wealth of Nations. New York: Bantam Dell.

SUSSMAN, N. and YAFEH, Y. (2006). Institutional Reforms, Financial Development and Sovereign Debt: Britain 1690 1790. The Journal of Economic History 66(4), pp. 906-35.

TEMIN, P. and VOTH, H-J. (2006). Banking as an emerging technology: Hoare's Bank, 17021742. Financial History Review 13(2), pp. 149-78.

The Times (1811). House of Commons, Wednesday May 15. [16 May 1811]. Consulted at The Times Digital Archive, 21 June 2016.

THORNTON, H. (1802). An Enquiry into the Nature and Effects of the Paper Credit of Great Britain. London

UGLOW, J. (2014). In These Times: Living in Britain through Napoleon's Wars, 1793-1815. London: Faber\&Faber.

VELDE, F.R., WEBER, W.E. and WRIGHT, R. (1999). A model of commodity money, with applications to Gresham's law and the debasement puzzle. Review of Economic Dynamics 2(1), pp. 291-323. 


\section{APPENDIX (for online publication only)}

\section{A1. The Bank of England and the money market}

London banks obtained their reserves from several sources including the deposits of clients (largely landowners and merchants), handling public funds en route to or from the Exchequer, deposits from country bankers and finally credit extended from the Bank of England itself (Joslin 1954, pp. 167, 176-7). Before 1797, the Bank did not permit London banks to rediscount bills of exchange, but this regulation could easily be circumvented by arrangements between the London bankers and one of the Bank of England's mercantile clients. But London banks could open drawing accounts at the Bank and borrow money in that way, and in 1793 just under half of them kept balances at the Bank (Clapham 2008a). As long as alternative ways existed for London bankers to obtain Bank notes and specie, direct and immediate control over their reserves could not be exercised by the Bank. Nevertheless, since the Directors determined the level of Bank notes and deposits in circulation, by expanding or contracting the Bank's credit they could ultimately affect the reserves of London Bankers.

The Bank incurred liabilities (issued notes or created deposits) in four ways: in exchange for gold or silver, as advances to individuals or firms, by discounting bills for the Government and by discounts for the private sector (Clapham 2008a, pp. 169, 172 and 204-5; Clapham 12008b, pp. 83-4). The exchange of Bank notes for gold did not add to the supply of reserve currency since gold already took that form, but advances and discounts for either the private or the public sector certainly did. The Bank followed normal banking practice and matched liabilities with assets and its accounts for the years 1789-91 show that about half of its liabilities were backed by public securities, 41 per cent by bullion, and the remainder by private assets. If the portion of notes and deposits backed by bullion is excluded from view and attention is focused on the monetization of private and public assets, it then appears that some 80 per cent of the Bank's outstanding liabilities in the years immediately before the war were incurred in the form of loans afforded to the state. This picture changed radically during the war years when the amount of reserves in the form of bullion held at the Bank fell sharply and discounts for the private sector became a more important proportion of total assets. ${ }^{72}$

\footnotetext{
72 The data on liabilities and assets of the Bank of England 1720-1815 refers to: Notes in Circulation; Drawing accounts; Private Deposits; Total Deposits; Bullion Reserves; Public Securities: Private Bills and Notes Discounted; Private Securities, and Miscellaneous. It can be reconstructed from statistics published by Clapham (2008a, 2008b) and Report from the Committee of Secrecy on the Expediency of Renewing the Charter of The Bank of England,
} 
The point to stress is that the creation of reserve money by the Bank of England originated as a response to requests for loans. By refusing to meet either Government or private demands the Bank could effectively curtail the supply of reserve money upon which London and indirectly provincial bankers conducted their operations and expanded credit. When the Treasury offered a larger amount of public securities (bills as well as bonds) directly to the money market (and the Bank of England concurrently failed to increase its discounts and advances to the private sector), bankers found themselves confronted with higher levels of demand for loans and credit. Unless they lowered the ratio of Bank notes and specie to outstanding liabilities, demands for loanable funds exceeded the available supplies and interest rates rose. Rates on public securities, unaffected by the operation of usury laws, inevitably went higher than rates on private bills, shares and mortgages.

As state assets were less risky and more liquid than mercantile bills of exchange, a greater share of the available supply of investible funds passed into the hands of the Government and the private sector experienced shortages of credit. Furthermore, the higher profits made on Government paper prompted clients of London bankers to withdraw their deposits (which paid no interest) in order to invest in liquid Government bills. This reduction or slower rise of cash deposited with London bankers reduced still further their capacities to create credit. Thus when pressure from the Bank forced the Treasury into the market and the market obtained no compensatory reserve money in the form of discounts from the Bank of England, facilities for borrowing money diminished and interest rates increased..$^{73}$

Although the Bank could only divert demands from the Treasury to the market, it held powers to refuse to discount bills or make advances to the private sector. In wartime when higher profits could be made from speculation in public securities, merchants, landowners, farmers and industrialists often found it difficult to secure accommodation from London bankers and turned to the Bank of England (Joslin 1954, Parliamentary Papers 1826, pp. 17, 43, 71, 145 and 207). Provided they expressed willingness to pay 5 per cent and the Bank complied with their requests, the level of private finance available would not fall. Moreover, as the Bank increased its loans the supply of reserve currency available to London bankers also rose and credit conditions in the metropolis did not become stringent.

Parliamentary Papers 1831-32 (volume 6) appendixes 5, 24 and 32. See also Bank of England (1967).

73 Parliamentary Papers 1826, pp. 22, 35-7, 43, 72, 157, 175, 178, 180, 191-2, 212, 303; Committee of the House of Commons on 10 Naval Report, Parliamentary Papers 1805 (5), pp. 42, 47 and 69; Thornton (1802, pp. 281,289 and 291); Boyd (1811); Minutes of the Committee of the Treasury of the Bank of England 15.4.96, 23.6.96 and 3.11.96; Pitt Papers 03/08/115; Auckland Papers BLAM 34454; Wakefield (1797, pp. 26 and 54) and Monthly Magazine (May 1796, p. 326 and July 1796, p. 498). 
But when the Bank behaved as it did between December, 1795 and February, 1797 (when the Directors not merely forced the Treasury into the market but rationed credit to the private sector at the same time), the private sector did experience real difficulty in raising funds and interest rates rose sharply. Moreover, the effects of the Bank's policy went beyond restriction in loans and reserve currency and adversely affected the confidence of London Bankers, who withheld accommodation and operated with higher reserve ratios. ${ }^{74}$ While the experience of $1795-97$ revealed clearly how the liquidity of the London money market depended on the credit policies of the Bank of England, the indirect dependence of banks outside the metropolis was only elucidated by Pressnell (1956). ${ }^{75}$

During the restriction period, controversy arose not on the problem of the Bank's relations with London banks, a subject generally ignored at the time, but about its influence upon issues by banks outside the metropolis. One school of thought, ("bullionists") maintained that the expansion of credit by country bankers could be determined by the Bank. Malthus, for example, considered it "a point of susceptible of complete demonstration that an increase in the issue of Bank of England notes is attended with a proportionate increase in the issue of country bank notes". ${ }^{76}$ On the other side, a few contemporary writers denied all connexion between the Bank of England and the note issues of country banks; Bosanquet (a Bank Director), and economists such as Wheatley and (Chancellor of the Exchequer) Vansittart came close to this position. ${ }^{77}$

Yet nearly all bankers who appeared before Parliamentary Committees investigating the monetary system during the war admitted they followed the lead of the Bank in the expansion and contraction of credit. ${ }^{78}$ Gilchrist, Chairman of the British Linen Bank, to take but one example, stated quite unequivocally that, "If the Bank of England were to restrict the issues of course

\footnotetext{
74 Parliamentary Papers 1826 (3), pp. 35-7, 173-5, 190 and 215, and Pitt Papers 30/8/115.

75 Although some appreciation of their subordinate position can be detected from the evidence of country bankers to Parliamentary Committees in 1797 and 1810 (Parliamentary Papers 1826, p. 179 and Parliamentary Papers 1810 , p. 113-5 and 140.)

${ }^{76}$ Malthus (1811, pp. 457-8). See also Ricardo (1951/1811, pp. 87-88); Boyd (1811, p. 23); Fetter (1957, p. 46); Parnell (1828) and Cannan (1925, p. 61).

${ }_{77}$ Bosanquet (1810, p. 78); Wheatley (1803, pp. 209-21); Parliamentary Papers (1803/4-1812, vols. 1-22; vols. 2331); See also Silberling (1924) and Angell (1926), who argue that the Bank exercised little influence over variations in the money supply. Note that Wheatley, while classified by O'Brien (2004) as a "rigid" bullionist, conceded that the country banks could increase their banknotes significantly by varying their reserve ratios, and could cause an expansion of Bank of England notes (given its apparent adherence to the Real Bills Doctrine) by discounting bills with the Bank in times of pressure (O'Brien 2004, p. 181).

${ }^{78}$ Committee of the House of Commons on Suspension, 1797, Parliamentary Papers 1826 (3), pp. 142, 190 and 212 ; Committee of the House of Commons on Bullion, together with Minutes off Evidence from the Select Committee on the High Price of Gold Bullion in Parliamentary Papers 1810 (3), pp. 141 and 143.
} 
Scots Banks would find it necessary to restrict their issues". ${ }^{79}$ Parliamentary reports had no doubt, to quote one, that "the Bank of England is at the head of circulation", or to cite another that the credit of private bankers was "a superstructure raised upon the foundation of the Bank of England". 80

Most contemporaries might well have shared such general opinions but the mechanisms through which the Bank brought about variations in the money supply at the end of the eighteenth century were not elucidated until modern times by Wood (1939), Clapham (2008a, b) and Pressnell (1956). Briefly stated, their conclusions are that the Bank affected the overall creation of credit by influencing the reserves of London banks and through them (indirectly) the reserves of banks located outside the metropolis. London bankers regulated the liabilities they incurred on reserves of specie and Bank notes. ${ }^{81}$

\section{A2. Construction of the warfare intensity variable}

Our proxy for warfare intensity is the number of casualties (dead or wounded, plus missing or captured soldiers) per capita, that is, relative to the population of Britain during that year. The source for the casualties is the latest (third) edition of Clodfelter (2008). We have built a new dataset for Britain which partly relies on, but also improves on, that of Dincecco and Prado (2012) in several ways. First, while they present country averages, our data is of a higher (yearly) frequency, which allows for time series analysis, albeit at the loss of a comparative dimension; second, while they only consider external conflicts for 1700-88 we consider the 1694-1699 and 1789-1815 periods as well; third, we include internal conflicts (such as the Jacobite risings of 1715 and 1745); finally, our measure is set in not only absolute (in the main text) but also in per capita terms (in this appendix, see Figure A2) as it is worthwhile to check that the results do not change when measuring conflict intensity in this time-comparable way. And indeed, the conclusions do not change.

An alternative measure would use total men mobilized. This has several disadvantages, however, when compared with our measure of "hot" war. First, unlike in the case of battle casual-

\footnotetext{
79 Committee of the House of Commons, Parliamentary Papers (1810, p. 114).

80 Committee of the House of Commons on Suspension, 1797, Parliamentary Papers (1826, pp. 142-62); Cannan (1925, p. 61); and Committee of the House of Commons on Bullion; Parliamentary Papers (1810 (3), pp. 90 and 13. For a recent analysis of the influence of the Bank of England on provincial banks, see O'Brien and Palma (2019).

${ }^{81}$ Committee of the House of Commons on Suspension, 1797; Parliamentary Papers (1826, pp. 35-7, 43 and 191-2); Boyd (1811, p. 23).
} 
ties, this data is much more often unavailable. Second, it is a more direct measure of present fiscal capacity, hence leading to confounding problems (countries with a larger population but weaker states have more difficulty recruiting and paying armies.) Finally, note that if a strong state is able to credibly threaten the formation of an efficient army this will scare enemies into strategically accepting conditions even without any causalities or even any mobilization at all.

We included casualties for all the major (as defined in Clodfelter 2008) land, coastal and sea battles, as well as sieges. Only British men were considered: hence Hessians for instance, were not, even though they were contracted by the British government. As with Dincecco and Prado (2012), our definition of casualties includes captured, wounded and missing soldiers, as well as those dead of diseases, which in the tropics could easily outnumber battle casualties. Unfortunately it is not possible to build an alternative measure which excludes these since Clodfelter often gives the joint number only. When a battle crossed over from a year to the next casualties were classified in the year which covers the majority of the time. If the battle spanned over more than two years, which was very rare and obviously only possible for sieges, we simply took the average. For several battles, Clodfelter gives the overall figure for Britain's side (e.g. the Allies during the war of the Spanish Succession) but does not break down the casualties of Britain, though often this is done. Indeed at times Clodfelter explicitly says the casualty numbers for Britain's side are unavailable. For the benchmark estimate for this variable we have taken the conservative choice and assumed Britain's casualties were proportional to those of its allies in that particular battle. So for instance, if Britain had two allies in that war, its casualty distribution toll was simply assumed to be one third. Finally, when the number of British casualties for a given battle is known, we used that number, but when a British ally entered a battle but Britain did not, we counted zero casualties for Britain.

Though a helpful estimate, this is likely to suffer from the following biases. If because of superior fiscal capacity Britain was putting in a larger share of soldiers for its alliances then it is not surprising that casualties would be superior as well, which suggests an underestimate of Britain's war effort. But an offsetting factor is that the benchmark estimate is not scaled by country population size or the location of the war (it is natural that it would be easier to mobilize an army of the same size for countries physically closer to the actual battle). 


\section{A3. Statistical tests}

\section{A3.1. Structural break tests}

We now perform a number of structural break tests, which are likelihood-ratio (or Wald) tests of whether the coefficients of a time-series regression of the size of fiat relative to coin supply vary over the periods defined by break dates are set a priori. ${ }^{82}$ Notice that unlike what is the case with familiar Chow tests, these tests are robust to unknown forms of heteroscedasticity.

The results are shown in Table A1. There are two test-type options. The first is to perform a test for a single, endogenously determined break. An alternative is to perform a multiple structural break test. For this second test, we need to set candidate dates. Both narrative historical evidence and the Figures 2 and 7 from the main text suggest possible breaks in 1797 and 1821 . For each test option, and for a variety of specifications and subsamples, we focus on the ratio of Bank of England notes to coin supply. ${ }^{83}$ The results are shown in columns (1) to8). Columns (7) and (8) confirm that there was stability prior to the Suspension.

Whether we specify the equation in levels or natural logs, we reject the null hypothesis of no-structural break at our key dates. ${ }^{84}$ These formal tests confirm that a structural break happened between 1796 and 1800, and another happened around 1821, a result also easily visible by inspection of Figures 2 and 7. In the case of single-break tests for the natural logs specifications - column (4) - the tests suggest that the break occurred in 1822, but this is because we are assuming that only one break occurred, while visual inspection of Figures 2 and 7 from the text suggests that at least two did. Indeed, this is what the multiple break tests in columns (5) and (6) show.

\section{A3.2. Unit root tests}

The break found in specification in columns (1), (3) is close to the trim, but at the same time, that of columns (2) and (4) is not clearly superior, not only because more than one break occurred - as suggested by the results of the multiple break test - but also because structural break tests may not be valid in the presence of unit roots (and vice versa). Since the distribution is stationary until 1790 , this is not a problem for that period. And the fact that a unit root ap-

\footnotetext{
${ }^{82}$ Our formal discussion of structural change is focused solely on the issue of testing parameter stability, and on the first moment of the distribution; cf. Stock (1994), Bai and Perron (1998), Perron (2006).

83 This is in fact a lower bound to the true notes/coin ratio, since the banknotes of provincial are not included.

84 There may have also been a small increase in the mean of the distribution in the first quarter of the eighteenth century.
} 
pears around the time of the Restriction Period is precisely the main point we are making. As visual inspection of Figure 7 from the main text suggests, the distribution gains a persistent upwards drift or trend after $1797 .{ }^{85}$ The bank Restriction Period of 1797-1821 is one of disruption, but after 1821 the distribution does not return to its pre-1797 mean.

We now formally test this visual conjecture using augmented Dickey-Fuller (ADF) tests. The results for the ratio of Bank of England notes to coin supply are in Table A2. For each specification, the number of lags has been chosen according to the BIC criteria. Starting with the full sample, nonstationarity cannot be rejected if no drift or trend terms are allowed (column 1), as we would expect from visual inspection of Figure 5 from the main text. Even if the sample is restricted to the pre-1797 period, nonstationarity is not rejected because of an early trend in the first quarter of the century (column 2); but if the sample is restricted to the 1726-1796 period, nonstationarity is safely rejected (column 3). As we would expect, extending the sample up to 1821 , and even excluding the pre-1726 period, the distribution is once again nonstationarity (column 4), a result that evidently also holds if the sample is instead extended to 1844. The same qualitative conclusions hold if the variable is set in natural logs rather than levels (Table A3).

${ }^{85}$ The alternative methodology of Figure 1 leads to the same pattern of results. 


\begin{tabular}{|c|c|c|c|c|c|c|c|c|}
\hline & (1) & $(2)$ & (3) & (4) & $(5)$ & $(6)$ & (7) & (8) \\
\hline Variable & $\mathrm{BoE} /$ coin & BoE/coin & $\mathrm{BoE} / \mathrm{coin}$ & $\mathrm{BoE} / \mathrm{coin}$ & BoE/coin & BoE/coin & BoE/coin & $\mathrm{BoE} / \mathrm{coin}$ \\
\hline $\begin{array}{l}\text { Type of } \\
\text { test }\end{array}$ & $\begin{array}{l}\text { Single, } \\
\text { unknown } \\
\text { break }\end{array}$ & $\begin{array}{l}\text { Single, un- } \\
\text { known } \\
\text { break }\end{array}$ & $\begin{array}{l}\text { Single, } \\
\text { unknown } \\
\text { break }\end{array}$ & $\begin{array}{l}\text { Single, un- } \\
\text { known } \\
\text { break }\end{array}$ & $\begin{array}{c}\text { Multiple } \\
\text { breaks: testing } \\
\text { for } 1797 \text { and } \\
1821\end{array}$ & $\begin{array}{c}\text { Multiple } \\
\text { breaks: } \\
\text { testing } \\
\text { for } 1797 \\
\text { and } 1721\end{array}$ & $\begin{array}{l}\text { Single, } \\
\text { unknown } \\
\text { break }\end{array}$ & $\begin{array}{l}\text { Single, } \\
\text { unknown } \\
\text { break }\end{array}$ \\
\hline $\begin{array}{l}\text { Specifica- } \\
\text { tion }\end{array}$ & Levels & Levels & $\begin{array}{c}\text { Natural } \\
\log s\end{array}$ & Natural logs & Levels & $\begin{array}{c}\text { Natural } \\
\text { logs }\end{array}$ & Levels & $\begin{array}{c}\text { Natural } \\
\log s\end{array}$ \\
\hline Period & $1696-1815$ & $\begin{array}{l}\text { 1696-1844 } \\
\text { (full sam- } \\
\text { ple) }\end{array}$ & $1696-1815$ & $\begin{array}{c}\text { 1696-1844 } \\
\text { (full sample) }\end{array}$ & $\begin{array}{c}\text { 1696-1844 } \\
\text { (full sample) }\end{array}$ & $\begin{array}{c}\text { 1696- } \\
1844 \\
\text { (full } \\
\text { sample) } \\
\end{array}$ & $\begin{array}{l}1696- \\
1797\end{array}$ & $\begin{array}{c}1696- \\
1797\end{array}$ \\
\hline $\begin{array}{c}\text { Observa- } \\
\text { tions }\end{array}$ & 120 & 149 & 120 & 149 & 149 & 149 & 101 & 101 \\
\hline $\begin{array}{l}\text { Outcome } \\
\text { at con- } \\
\text { ventional } \\
\text { levels }\end{array}$ & $\begin{array}{l}\text { Break date } \\
\text { detected in } \\
1798\end{array}$ & $\begin{array}{c}\text { Break date } \\
\text { detected in } \\
\quad 1802\end{array}$ & $\begin{array}{l}\text { Break date } \\
\text { detected in } \\
\quad 1796\end{array}$ & $\begin{array}{l}\text { Break date } \\
\text { detected in } \\
1822\end{array}$ & $\begin{array}{c}1797 \text { and } 1821 \\
\text { detected as } \\
\text { breakpoints }\end{array}$ & $\begin{array}{c}1797 \text { and } \\
1821 \\
\text { detected } \\
\text { as break- } \\
\text { points }\end{array}$ & $\begin{array}{l}\text { Cannot } \\
\text { reject no } \\
\text { structur- } \\
\text { al break }\end{array}$ & $\begin{array}{l}\text { Cannot } \\
\text { reject no } \\
\text { structur- } \\
\text { al break }\end{array}$ \\
\hline $\mathrm{p}$-value & 0.00 & 0.00 & 0.00 & 0.00 & 0.00 & 0.00 & 0.00 & 0.00 \\
\hline
\end{tabular}

Table A1. Structural break tests following a time-series regression of the "BoE notes/coin” variable on a constant and a time (years) variable; standard errors are robust the trim is $15 \%$. 


\begin{tabular}{|c|c|c|c|c|c|c|c|c|c|c|c|c|}
\hline & (1) & $(2)$ & (3) & $(4)$ & $(5)$ & (6) & (7) & (8) & (9) & (10) & (11) & $(12)$ \\
\hline Variable & BoE/coin & $\mathrm{BoE} /$ coin & BoE/coin & BoE/coin & BoE/coin & BoE/coin & BoE/coin & BoE/coin & BoE/coin & BoE/coin & BoE/coin & BoE/coin \\
\hline Type of test & $\begin{array}{c}\text { No drift and } \\
\text { no trend }\end{array}$ & $\begin{array}{c}\text { No drift and } \\
\text { no trend }\end{array}$ & $\begin{array}{c}\text { No drift and no } \\
\text { trend }\end{array}$ & $\begin{array}{c}\text { No drift and } \\
\text { no trend }\end{array}$ & $\begin{array}{c}\text { Drift } \\
\text { included }\end{array}$ & $\begin{array}{c}\text { Drift } \\
\text { included }\end{array}$ & $\begin{array}{c}\text { Drift } \\
\text { included }\end{array}$ & $\begin{array}{c}\text { Drift } \\
\text { included }\end{array}$ & $\begin{array}{c}\text { Trend } \\
\text { included }\end{array}$ & $\begin{array}{c}\text { Trend } \\
\text { included }\end{array}$ & $\begin{array}{c}\text { Trend } \\
\text { included }\end{array}$ & $\begin{array}{c}\text { Trend } \\
\text { included }\end{array}$ \\
\hline Specification & Levels, 1 lag & Levels, 1 lag & $\begin{array}{l}\text { Levels, } \\
1 \text { lag }\end{array}$ & $\begin{array}{c}\text { Levels, } \\
1 \text { lag }\end{array}$ & $\begin{array}{c}\text { Levels, } \\
1 \text { lag }\end{array}$ & $\begin{array}{c}\text { Levels, } \\
1 \text { lag }\end{array}$ & $\begin{array}{c}\text { Levels, } \\
1 \text { lag }\end{array}$ & $\begin{array}{c}\text { Levels, } \\
1 \text { lag }\end{array}$ & $\begin{array}{c}\text { Levels, } \\
1 \text { lag }\end{array}$ & $\begin{array}{c}\text { Levels, } \\
1 \text { lag }\end{array}$ & $\begin{array}{c}\text { Levels, } \\
1 \text { lag }\end{array}$ & $\begin{array}{c}\text { Levels, } \\
1 \text { lag }\end{array}$ \\
\hline Period & $\begin{array}{c}\text { 1696-1844 } \\
\text { (full sample) }\end{array}$ & $1696-1796$ & $1726-1796$ & $1726-1821$ & $\begin{array}{c}1696-1844 \\
\text { (full sample) }\end{array}$ & $1696-1796$ & $1726-1796$ & $1726-1821$ & $\begin{array}{c}\text { 1696-1844 } \\
\text { (full sample) }\end{array}$ & 1696-1796 & 1726-1796 & $1726-1821$ \\
\hline Observations & 147 & 99 & 71 & 96 & 147 & 99 & 71 & 96 & 147 & 99 & 71 & 96 \\
\hline $\begin{array}{c}\text { Outcome at } \\
\text { conventional } \\
\text { levels }\end{array}$ & $\begin{array}{l}\text { Cannot } \\
\text { reject non- } \\
\text { stationarity }\end{array}$ & $\begin{array}{l}\text { Cannot } \\
\text { reject non- } \\
\text { stationarity }\end{array}$ & $\begin{array}{c}\text { Reject nonsta- } \\
\text { tionarity }\end{array}$ & $\begin{array}{l}\text { Cannot } \\
\text { reject non- } \\
\text { stationarity }\end{array}$ & $\begin{array}{c}\text { Cannot } \\
\text { reject non- } \\
\text { stationarity } \\
\text { at } 1 \% \text { and } \\
5 \% \text {, reject at } \\
10 \%\end{array}$ & $\begin{array}{c}\text { Cannot } \\
\text { reject non- } \\
\text { stationarity } \\
\text { at } 1 \% \text {, reject } \\
\text { at } 5 \%\end{array}$ & $\begin{array}{l}\text { Reject nonsta- } \\
\text { tionarity }\end{array}$ & $\begin{array}{l}\text { Cannot } \\
\text { reject non- } \\
\text { stationarity }\end{array}$ & $\begin{array}{l}\text { Cannot } \\
\text { reject nonsta- } \\
\text { tionarity }\end{array}$ & $\begin{array}{l}\text { Cannot } \\
\text { reject non- } \\
\text { stationarity }\end{array}$ & $\begin{array}{c}\text { Reject } \\
\text { nonstation- } \\
\text { arity }\end{array}$ & $\begin{array}{l}\text { Cannot } \\
\text { reject non- } \\
\text { stationarity }\end{array}$ \\
\hline $\begin{array}{c}\text { MacKinnon } \\
\text { approximate } \\
\text { p-value }\end{array}$ & 0.5423 & 0.2596 & 0.00 & 0.6532 & 0.0702 & 0.0209 & 0.0000 & 0.1078 & 0.1988 & 0.1390 & 0.0046 & 0.5705 \\
\hline
\end{tabular}

Table A2. ADF tests for the "Bank of England notes/coin supply" variable 


\begin{tabular}{|c|c|c|c|c|c|c|c|c|c|c|c|c|}
\hline & (1) & $(2)$ & (3) & $(4)$ & $(5)$ & (6) & (7) & (8) & (9) & (10) & (11) & $(12)$ \\
\hline Variable & $\mathrm{BoE} / \mathrm{coin}$ & BoE/coin & $\mathrm{BoE} / \mathrm{coin}$ & $\mathrm{BoE} / \mathrm{coin}$ & $\mathrm{BoE} / \mathrm{coin}$ & $\mathrm{BoE} / \mathrm{coin}$ & $\mathrm{BoE} / \mathrm{coin}$ & $\mathrm{BoE} / \mathrm{coin}$ & $\mathrm{BoE} /$ coin & $\mathrm{BoE} /$ coin & $\mathrm{BoE} /$ coin & $\mathrm{BoE} /$ coin \\
\hline Type of test & $\begin{array}{l}\text { No drift and } \\
\text { no trend }\end{array}$ & $\begin{array}{c}\text { No drift and } \\
\text { no trend }\end{array}$ & $\begin{array}{c}\text { No drift and no } \\
\text { trend }\end{array}$ & $\begin{array}{c}\text { No drift and } \\
\text { no trend }\end{array}$ & $\begin{array}{c}\text { Drift } \\
\text { included }\end{array}$ & $\begin{array}{c}\text { Drift } \\
\text { included }\end{array}$ & $\begin{array}{c}\text { Drift } \\
\text { included }\end{array}$ & $\begin{array}{c}\text { Drift } \\
\text { included }\end{array}$ & $\begin{array}{c}\text { Trend } \\
\text { included }\end{array}$ & $\begin{array}{c}\text { Trend } \\
\text { included }\end{array}$ & $\begin{array}{c}\text { Trend } \\
\text { included }\end{array}$ & $\begin{array}{c}\text { Trend } \\
\text { included }\end{array}$ \\
\hline Specification & Ln, 1 lag & Ln, 1 lag & $\begin{array}{l}\text { Ln, } \\
1 \text { lag }\end{array}$ & $\begin{array}{l}\text { Levels, } \\
1 \text { lag }\end{array}$ & $\begin{array}{l}\text { Ln, } \\
1 \text { lag }\end{array}$ & $\begin{array}{l}\text { Ln, } \\
1 \text { lag }\end{array}$ & $\begin{array}{l}\text { Ln, } \\
1 \text { lag }\end{array}$ & $\begin{array}{l}\text { Ln, } \\
1 \text { lag }\end{array}$ & $\begin{array}{l}\text { Ln, } \\
1 \text { lag }\end{array}$ & $\begin{array}{l}\text { Ln, } \\
1 \text { lag }\end{array}$ & $\begin{array}{l}\text { Ln, } \\
1 \text { lag }\end{array}$ & $\begin{array}{l}\text { Ln, } \\
1 \text { lag }\end{array}$ \\
\hline Period & $\begin{array}{c}\text { 1696-1844 } \\
\text { (full sample) }\end{array}$ & $1696-1796$ & $1726-1796$ & $1726-1821$ & $\begin{array}{c}\text { 1696-1844 } \\
\text { (full sample) }\end{array}$ & $1696-1796$ & $1726-1796$ & $1726-1821$ & $\begin{array}{c}\text { 1696-1844 } \\
\text { (full sample) }\end{array}$ & $1696-1796$ & $1726-1796$ & $1726-1821$ \\
\hline Observations & 147 & 99 & 71 & 96 & 147 & 99 & 71 & 96 & 147 & 99 & 71 & 96 \\
\hline $\begin{array}{c}\text { Outcome at } \\
\text { conventional } \\
\text { levels }\end{array}$ & $\begin{array}{l}\text { Cannot } \\
\text { reject non- } \\
\text { stationarity }\end{array}$ & $\begin{array}{c}\text { Cannot reject } \\
\text { nonstation- } \\
\text { arity }\end{array}$ & $\begin{array}{c}\text { Reject nonsta- } \\
\text { tionarity }\end{array}$ & $\begin{array}{l}\text { Cannot } \\
\text { reject non- } \\
\text { stationarity }\end{array}$ & $\begin{array}{l}\text { Cannot } \\
\text { reject non- } \\
\text { stationarity }\end{array}$ & $\begin{array}{c}\text { Cannot } \\
\text { reject non- } \\
\text { stationarity } \\
\text { at } 1 \% \text {, reject } \\
\text { at } 5 \%\end{array}$ & $\begin{array}{c}\text { Reject nonsta- } \\
\text { tionarity }\end{array}$ & $\begin{array}{l}\text { Cannot } \\
\text { reject non- } \\
\text { stationarity }\end{array}$ & $\begin{array}{l}\text { Cannot } \\
\text { reject nonsta- } \\
\text { tionarity }\end{array}$ & $\begin{array}{l}\text { Cannot } \\
\text { reject nonsta- } \\
\text { tionarity }\end{array}$ & $\begin{array}{c}\text { Reject } \\
\text { nonstation- } \\
\text { arity }\end{array}$ & $\begin{array}{l}\text { Cannot } \\
\text { reject non- } \\
\text { stationarity }\end{array}$ \\
\hline $\begin{array}{c}\text { MacKinnon } \\
\text { approximate } \\
\text { p-value }\end{array}$ & 0.8886 & 0.2422 & 0.0005 & 0.9585 & 0.3029 & 0.0189 & 0.0000 & 0.4997 & 0.3167 & 0.1228 & 0.0034 & 0.9377 \\
\hline
\end{tabular}

Table A3. ADF tests for the "Bank of England notes/coin supply" variable, using a natural logarithm specification. 


\section{Appendix references}

\section{Primary Sources}

BOSANQUET, C. (1810). Practical observations on the report of the Bullion-Committee. Consulted at the Goldsmiths Collection, University of London Library.

BOYD, W. (1811). A letter to the Right Honourable William Pitt: on the influence of the stoppage of issues in specie at the Bank of England: on the prices of provisions, and other commodities. Consulted at the Goldsmiths Collection, University of London Library.

Monthly Magazine (May 1796 and July 1796), British Library.

PARNELL, H. (1828). Observations on Paper Money. Consulted at the Goldsmiths Collection, University of London.

Parliamentary Papers 1810, 1826, British Library.

Pitt Papers (Papers of Pitt the Younger), The National Archives, 03/08/115

\section{$\underline{\text { Secondary Sources }}$}

ANGELL, J.W. (1926). The theory of international prices. Cambridge: Harvard University Press.

BAI, J. and PERRON, P. (1998). Estimating and testing linear models with multiple structural changes. Econometrica 66(1), pp. 47-78.

Bank of England (1967). Bank of England Liabilities and Assets: 1696 to 1966. Quarterly Bulletin, June edition. Available at http://www.bankofengland.co.uk/archive/Documents/historicpubs/qb/1967/qb67q2appendix 159163.pdf, Accessed August 13, 2014.

CANNAN, E. (19t25). The Paper Pound 1797-1821. London: P.S. King\&Son.

CLAPHAM, J. (2008a). The Bank of England: A History. Volume 1: Cambridge University Press. Paperback reprint of the 1944 edition.

CLAPHAM, J. (2008b). The Bank of England: A History. Volume 2: Cambridge University Press. Paperback reprint of the 1944 edition. 
CLODFELTER, M. (2008). Warfare and Armed Conflicts: A Statistical Reference to Casualty and Other Figures 1494-2007. Jefferson, NC: McFarland.

DINCECCO, M. and PRADO, M. (2012). Warfare, Fiscal Capacity, and Performance. Journal of Economic Growth 17, pp. 171-203.

FETTER, F.W. (ed) (1957). Economic Writings of Francis Horner in Edinburgh Review, 1802-6. New York: Kelley and Millan.

JOSLIN, D.M. (1954). London Private Bankers, 1720-1785. Economic History Review 8, reprinted in J. Pressnell, Studies in the Industrial Revolution (original edition, 1960).

MALTHUS, T.R. (1811). Review of the Controversy. Consulted at the Goldsmiths Collection, University of London Library.

O’BRIEN, D. P. (2004). The Classical Economists Revisited. Princeton, Oxford: Princeton University Press.

PERRON, P. (2006). Dealing with structural breaks. In K. Patterson and T.C. Mills (eds), Palgrave handbook of econometrics 1. London: Palgrave Macmillan.

PRESSNELL, L.S. (1956). Country Banking in the Industrial Revolution. Oxford: Clarendon Press.

RICARDO, D. (1951/1811). High Price of Bullion, in P. Sraffa (ed), Works 3

SILBERLiNG, N. (1924). Financial and Monetary Policy of Great Britain during the Napoleonic Wars. Quarterly Journal of Economics 38(2), pp. 214-33.

STOCK, J.H. (1994). Unit Roots, Structural Breaks and Trends. In R.F. Engel and D.L. McFadden (eds), Handbook of Econometrics IV. New York: North Holland, pp. 2740-841.

WAKEFIELD, G. (1797). Observations on the credit and finances of Great Britain. London: Printed for F. and C. Rivington.

WHEATLEY, J. (1803). Remarks on Currency and Commerce. Consulted at the Goldsmiths Collection, University of London Library. Also: https://archive.org/details/remarksoncurrenc07whea

WOOD, E. (1939). English Theories of Central Bank Control. Cambridge, Massachusetts: Harvard University Press. 


\section{ONLINE APPENDIX FIGURES}

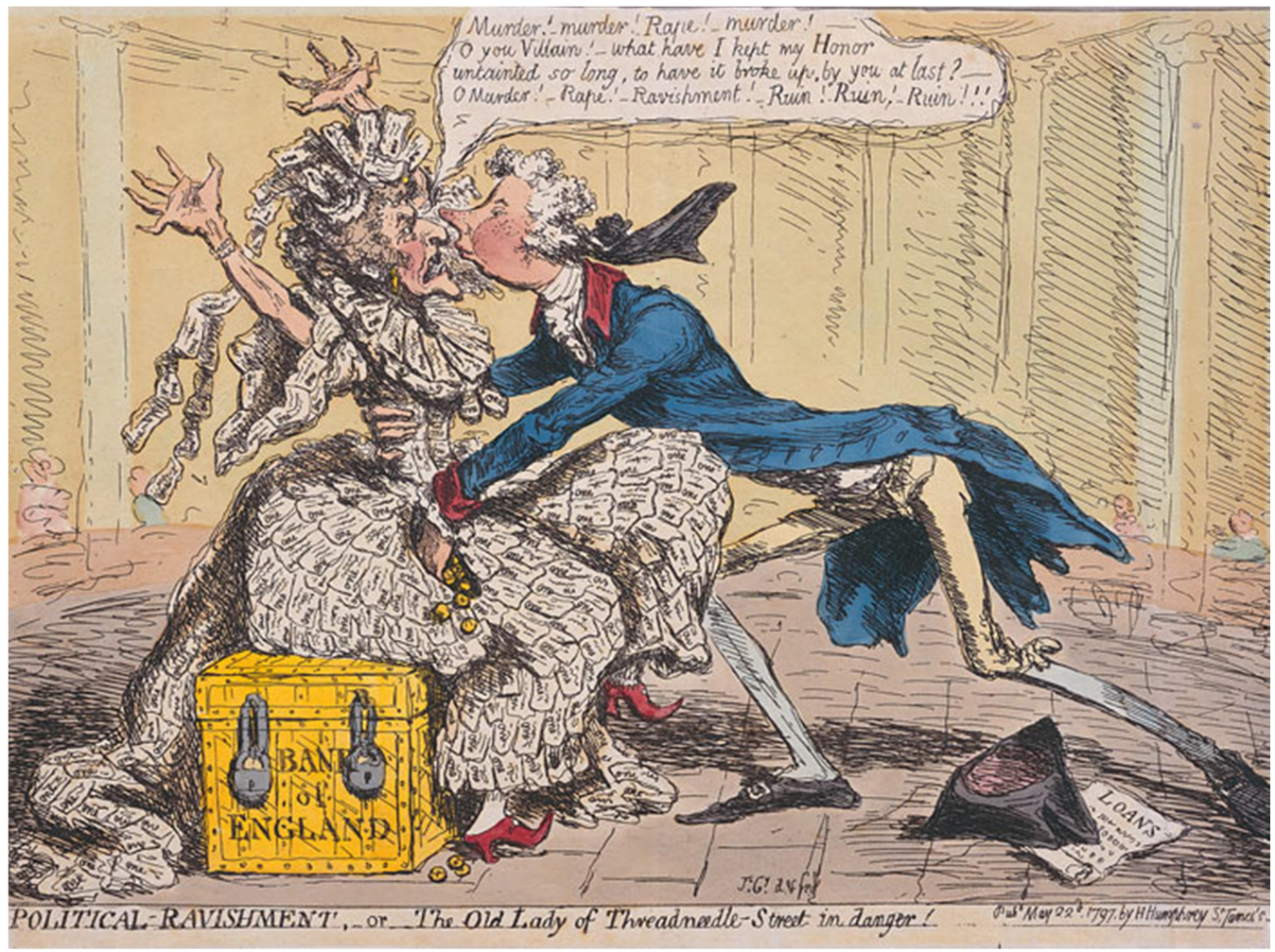

Figure A1. The Old Lady of Threadneedle Street in Danger, by James Gillray. Published at Hannah Humphrey's print shop on St. James Street, London, May $27^{\text {th }}, 1797$.

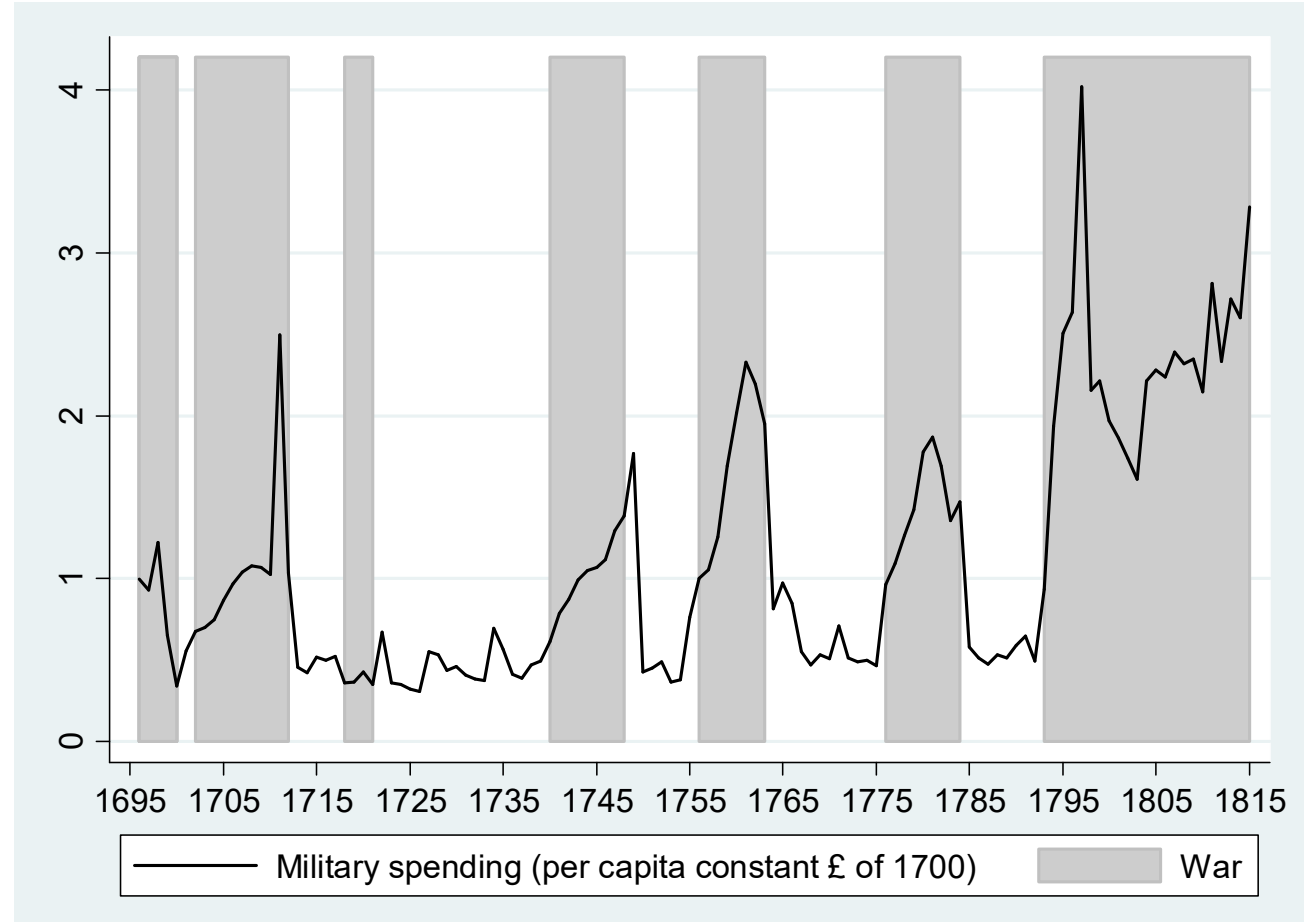

Figure A2. Real military spending in per capita terms and war. Sources: For naval and military spending, O'Brien and Duran (2010), for the deflator and population levels, Broadberry et al (2015). 


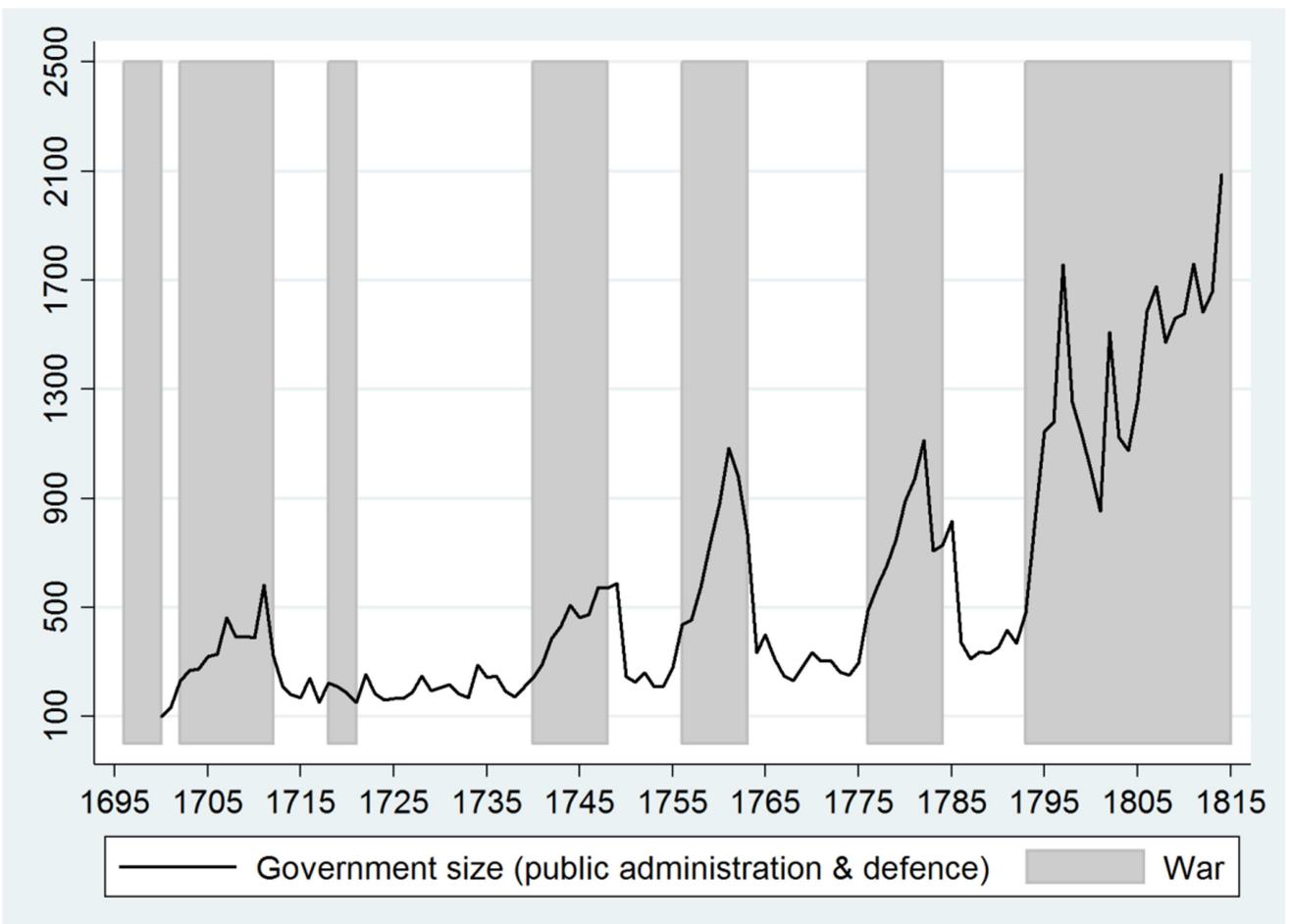

Figure A3. Government size and war (unit: Index, 1700=100). Source: Broadberry et al (2015).

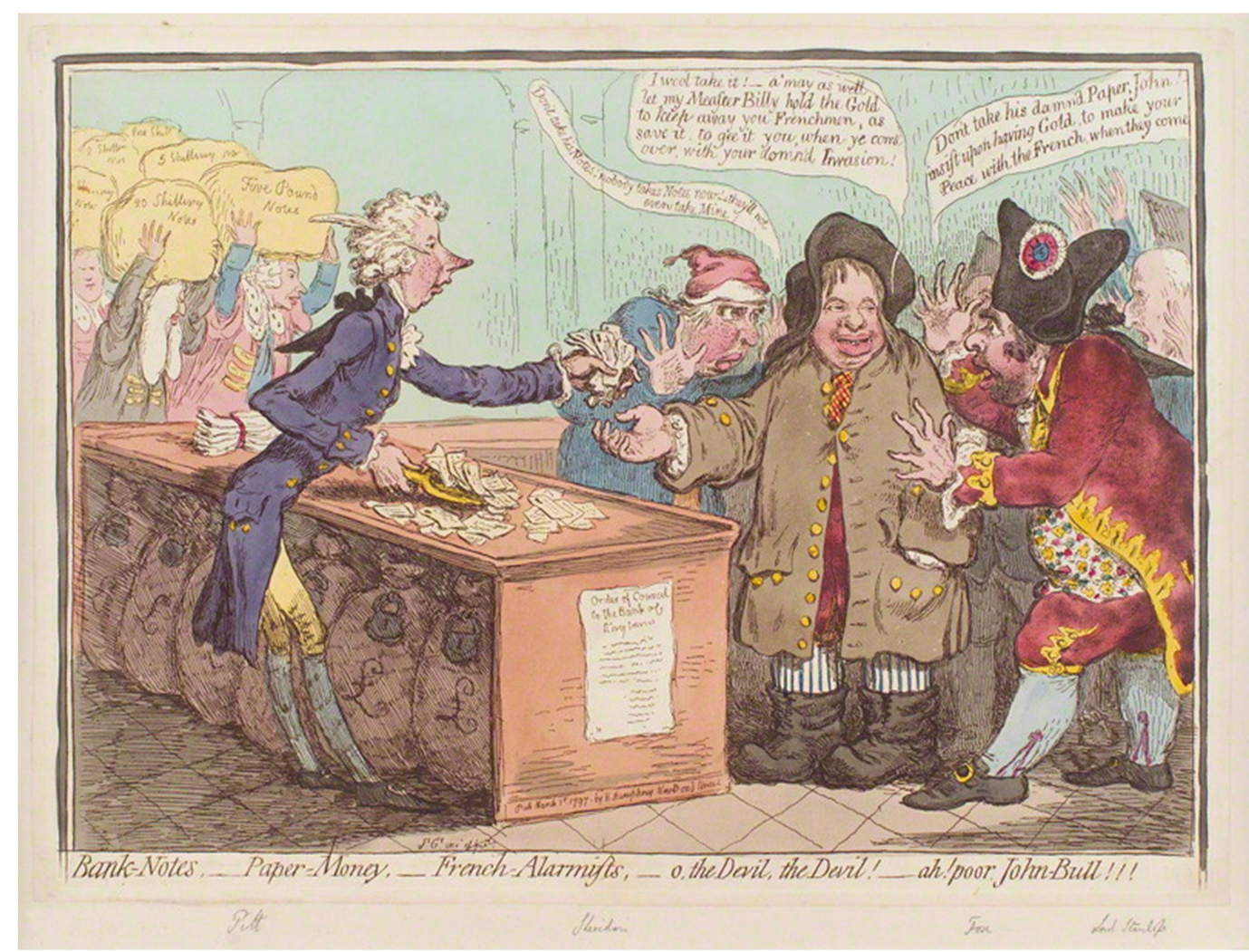

Figure A4. John Bull accepts paper money despite the warnings of French alarmists, by James Gillray. Published at Hannah Humphrey's print shop on St. James Street, London, March 1 ${ }^{\text {st }} 1797$. 